\title{
Porous Media Experience Applicable to Field Evaluation for Compressed Air Energy Storage
}

R. D. Allen

P. J. Gutknecht

June 1980

Prepared for the U.S. Department of Energy under Contract DE-AC06-76RLO 1830

Pacific Northwest Laboratory

Operated for the U.S. Department of Energy

by Battelle Memorial Institute 
NOTICE

This report was prepared as an account of work sponsored by the United States Government. Neither the United States nor the Department of Energy, nor any of their employees, nor any of their contractors, subcontractors, or their employees, makes any warranty, express or implied, or assumes any legal liability or responsibility for the accuracy. completeness or usefulness of any information, apparatus, product or process disclosed, or represents that its use would not infringe privately owned rights.

The views, opinions and conclusions contained in this report are those of the contractor and do not necessarily represent those of the United States Government or the United States Department of Energy.

\author{
PACIFIC NORTHWEST LABORATORY \\ operated by \\ BATTELLE \\ for the \\ UNITED STATES DEPARTMENT OF ENERGY \\ Under Contract DE-AC06-76RLO 1830
}

\author{
Printed in the United States of America \\ Available from \\ National Technical Information Service \\ United States Department of Commerce \\ 5285 Port Royal Road \\ Springfield, Virginia 22151
}

Price: Printed Copy \$ $\therefore$ Microfiche $\$ 3.00$

NTIS

•Pages Selling Price

$\begin{array}{ll}001-025 & \$ 4.00 \\ 026-050 & \$ 4.50 \\ 051-075 & \$ 5.25 \\ 076-100 & \$ 6.00 \\ 101-125 & \$ 6.50 \\ 126-150 & \$ 7.25 \\ 151-175 & \$ 8.00 \\ 176-200 & \$ 9.00 \\ 201-225 & \$ 9.25 \\ 226-250 & \$ 9.50 \\ 251-275 & \$ 10.75 \\ 276-300 & \$ 11.00\end{array}$




\section{0}

POROUS MEDIA EXPERIENCE

APPLICABLE TO FIELD EVALUATION

FOR COMPRESSED AIR ENERGY

STORAGE

R. D. Allen

P. J. Gutknecht

June 1980

Prepared for

the U.S. Department of Energy

under Contract DE-AC06-76RLO 1830

Pacific Northwest Laboratory

Richland, Washington 99352 
$\bullet$ 
FOREWORD

The Compressed Air Energy Storage Technology Program at the Pacific Northwest Laboratory (PNL) is sponsored by the Department of Energy, Divisions of Energy Storage Systems and Electric Energy Systems. The program scope includes a group of studies directed at developing a new energy storage technology to improve the cost and efficiency of electrical power utilization and reducing the dependence on petroleum fuels such as oil and natural gas. The program has two major thrusts --- Reservoir Stability Criteria Studies and Advanced Concepts Studies. These have the following objectives:

- Reservoir Stability Criteria

Develop design and stability criteria for long-term operation of underground reservoirs used for compressed air energy storage (CAES) in order to accelerate the commercialization of the concept.

- Advanced Concepts Studies

Develop and assess advanced CAES concepts that require little or no supplementary firing by petroleum fuels in order to eliminate the dependence of CAES on petroleum fuels.

The ultimate objective of this program is to reduce the consumption of natural gas and 011 used for peak-power generation plants by about $100,000,000$ barrels per year. This could be accomplished by replacing conventional gas turbine peaking plants currently being used by utilities with CAES plants.

The following documents have been issued or are in process by PNL or by subcontractors to PNL, reporting the results of the work toward these objectives.

- Technical and Economic Feasibility Analys is of the No-Fuel Compressed Air Energy Storage Concept, D.K. Kreid, BNWL-2065, May 1976.

- FY-1977 Progress Report - Stability and Design Criteria Studies for Compressed Air Energy Storage Reservoirs, G.C. Smith, J.A. Stottlemyre, L.E. Wiles, W.V. Loscutoff and H.J. Pincus, PNL-2443 March 1978. 
- FY-1977 Progress Report Compressed Air Energy Storage Advanced Systems Analysis, D.K. Kreid and M.A. McKinnon, PILl-2464, March 1978.

- Preliminary Stability Criteria for Compressed Air Energy Storage in Porous Media Reservoirs, J.A. Stottlemyre, PNL-2685, June 1978.

- Prel iminary Long-Term Stability Criteria for Compressed Air Energy Storage Caverns in Salt Domes, R.L. Thoms and J.D. Martinez, PNL-2871, August 1978.

- Numerical Analysis of Temperature and Flow Effects in a Dry, OneDimensional Aquifer Used for Compressed Air Energy Storage, G. C. Smith, L.E. Wiles, and W.V. Loscutoff, PNL-2546, February 1979.

- The Effects of Water on Compressed Air Energy Storage in Porous Rock Reservoirs, L.E. Wiles, PNL-2869, March 1979.

- Pacific Northwest Laboratory Annual Report for 1978 to the DOE Division of Energy Storage Systems - Compressed Air Energy Storage Technology Program, W. V. Loscutoff, PNL-2935, June 1979.

- Incremental Cost Analysis of Advanced Concept CAES Systems, C.A. Knutsen, Knutsen Research Services, Bothe11, WA, PNL-3118, September 1979.

- Numerical Analysis of Temperature and Flow Effects in a Dry, TwoDimensional, Porous-Media Reservoir Used for Compressed Air Energy Storage, L.E. Wiles, PNL-3047, October 1979.

- Potential Petrophysical and Chemical Property Alterations in a Compressed Air Energy Storage Porous Rock Reservoir, J.A. Stottlemyre, R.L. Erikson and R.P. Smith, PNL-2974, October 1979.

- The Economics of Compressed Air Energy Storage Employing Thermal Energy Storage, S. C. Schulte and R. W. Reilly, PNL-3191, November 1979.

- Structural Analysis of Porous Rock Reservoirs Subjected to Conditions of Compressed Air Energy Storage, J.R. Friley, PNL-3231, January 1980. 
- Compressed Air Energy Storage Technology Program Annual Report for 1979, W.V. Loscutoff, Staff Members and Subcontractors of Pacific Northwest Laboratory, PNL-3395, June 1980.

- CAES and UPHS in Hard Rock Caverns: I. Geological and Geotechnical Aspects, D.S. Port-Keller and P.F. Gnirk, Re/Spec Inc., Rapid City, SD, PNL-2886 (RSI-0076), In process.

- CAES and UPHS in Hard Rock Caverns: III. Preliminary Stability and Design Criteria for Compressed Air Energy Storage Caverns, P.F. Gnirk, Re/Spec Inc., Rapid City, SD, PNL-2916 (RSI-0079), In process.

- CAES and UPHS in Hard Rock Caverns: IV. Preliminary Stability and Design Criteria for Underground Pumped Hydro Storage Caverns, P.F. Gnirk, Re/Spec Inc., Rapid City, SD, PNL-3262 (RSI-0110), In process.

- Prel iminary Report on Numerical Model ing of the Behavior of Caverns in Salt for Compressed Air Energy Storage (CAES) Part I - Literature and Data Base Review, Serata Geomechanics Inc., Berkeley, CA, PNL-2887, In process.

- Prel iminary Report on Numerical Modeling of the Behavior of Caverns in Salt for Compressed Air Energy Storage (CAES) Part II - Laboratory Testing, Serata Geomechanics Inc., Berkeley, CA, PNL-2962, In process. 
. 
This report is a survey of porous media field experience that may lend technology to the development of a compressed air energy storage field demonstration. The literature search involved the review of work done at PNL and experience of other groups and related industries.

Section 1.0 provides an introduction. Section 2.0 gives the conclusions and recommendations from the study.

Section 3.0 is an overall view of porous media experience in the underground storage of fluids. CAES experience consists of site evaluation and selection processes used by groups in California, Kansas and Indiana. Reservoir design and field evaluation of example sites are reported. The studies raised questions about compatibility with depleted $0 i 1$ and gas reservoirs, storage space rights and compressed air regulations. Related experience (Section 3.2) embraces technologies of natural gas, thermal energy, geothermal and hydrogen storage. Natural gas storage technology lends the most toward compressed air storage development, keeping in mind the respective differences between stored fluids, physical conditions, and cycling frequencies. Both fluids are injected under pressure into an aquifer to form a storage bubble confined between a suitable caprock structure and partially displaced ground water.

State-of-the-art information is summarized in Section 4.0 as the necessary foundation material for field planning. Preliminary design criteria, as formulated by Stottlemyre et al (1979), are given as recommendations for basic reservoir characteristics. These include geometric dimensions and storage matrix properties such as permeability. Suggested ranges are given for injection air temperature and reservoir pressure. The second step in developmental research is numerical modeling. Results have aided preliminary design by analyzing injection effects upon reservoir pressure, temperature and humidity profiles. Third, results are reported from laboratory experiments on candidate sandstones and caprocks. Conclusions are drawn here, but further verification must be done in the field. 

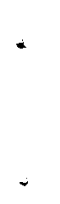


\section{CONTENTS}

Page

FOREWORD. . . . . . . . . . . . . . . . . . . .

SUMMARY . . . . . . . . . . . . . . . . . . . vii

FIGURES . . . . . . . . . . . . . . . . . . xi

TABLES. . . . . . . . . . . . . . . . . . . xi

1.0 INTRODUCTION . . . . . . . . . . . . . . . . . 1

2.0 CONCLUSIONS AND RECOMMENDATIONS. . . . . . . . . . . 7

3.0 POROUS MEDIA FIELD EXPERIENCE. . . . . . . . . . . . . 11

3.1 COMPRESSED AIR ENERGY STORAGE EXPERIENCE. . . . . . . 11

3.1.1 California ................ 11

3.1 .2 Kansas............... 12

3.1.3 Strata Power of Indiana. . . . . . . . 15

3.1.4 Applications to CAES Field Development . . . 19

3.2 RELATED EXPERIENCE. . . . . . . . . . . . . . . 19

3.2.1 Natural Gas Storage. . . . . . . . . . 19

3.2.1.1 Storage Reservoir ........ 20

3.2.1.2 Closure and Caprock ....... . 23

3.2.1.3 Storage Development and Monitoring. . 28

3.2.1.4 Natural Gas Storage Experience. . . . 31

3.2.1.5 Applications to Aquifer CAES. . . . 35

3.2.2 Thermal Energy Storage . . . . . . . . 37

3.2.2.1 Texas A\&M University. . . . . . . 37

3.2.2.2 Auburn University . . . . . . . 38

3.2.2.3 Petroleum Experience in Water Injection.......... . . 42

3.2.2.4 Seasonal Thermal Energy Storage (STES). . . . . . . . . . 45

3.2.2.5 Applications to Aquifer CAES. . . . 45

3.2.3 Geothermal Energy. . . . . . . . . . . 47

3.2.3.1 Site Evaluation ......... . 47

3.2.3.2 Reservoir Engineering . . . . . 48

3.2.3.3 Well Field Monitoring . . . . . . 51

3.2.3.4 Applications to Aquifer CAES. . . . 51 


$$
\begin{aligned}
& \text { Page } \\
& \text { 3.2.4 Hydrogen Storage. . . . . . . . } 52 \\
& \text { 3.2.4.1 Aquifer Storage. . . . . . . . } 52 \\
& \text { 3.2.4.2 Depleted Gas Fields. . . . . . . . } 56 \\
& \text { 3.2.4.3 Applications to Aquifer CAES . . . . } 56
\end{aligned}
$$

4.0 STATE-OF-THE-ART IN POROUS MEDIA CAES RESEARCH AT PNL . . . 59

4.1 PRELIMINARY DESIGN CRITERIA. . . . . . . . . . . . . . 59

4.2 NUMERICAL MODELING . . . . . . . . . . . . . 62

4.3 LABORATORY EXPERIMENTS . . . . . . . . . . . . 71

REFERENCES ..................... 77 


\section{FIGURES}

Page

1. Flow Diagram for Compressed Air Storage Plant (Stottlemyre et al 1979). . . . . . . . . . . . . . . .

2. Potential Areas for Aquifer Storage in the United States (Weinstein et al 1978) . . . . . . . . . . . . .

3. Threshold Pressure Versus Permeability (Katz and Lady 1976).

4. Geological Section Showing Reef and Drape Structure in the Calcutta Carbon Field (Lang 1975) . . . . . . . .

5. A Porous Medium Storage Container (Katz and Lady 1976) . . .

6. Effect of Changes in Barometer Pressure on Water Leve] in Open Well on Undisturbed Aquifer (Katz and Coats 1968). . .

7. Effect of Time on the Pressure Distribution in Aquifers (Katz and Lady 1976) ...................

8. Gas Wafering During Initial Injection in Aquifer (Katz and Lady 1976)......................

9. Reduction of Effective Closure by Facies Change (Rudd

10. Pump Test Evaluation of Caprock (Rudd 1979). . . . . . . . 27

11. Storage System (Katz and Lady 1976)............. . 29

12. Reservoir Pressure Behavior for Leaking and Nonleaking Aquifers (Katz and Lady 1976). . . . . . . . . . . .

13. Artist's Conception of Vent Gas Cycling System at Herscher (Katz and Lady 1976). . . . . . . . . . . .

14. Schematic of Second Aquifer Experiment at Auburn University . . . . . . . . . . . . . . . . 40

15. Aquifer Storage (Randolph et al 1978). . . . . . . . . 55

16. Schematic of an Aquifer System (Stottlemyre et al 1979). . . 60

17. Single Well Reservoir Within CAES Reservoir (Smith and

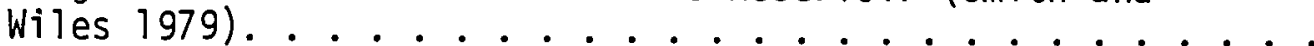


Page

18. One-Dimensional Radial Reservoir (Smith and Wiles 1979). . . 63

19. Dehydration for Three Locations (5-Year History) (WiTes and Oster 1978)................ 


\section{TABLES}

Page

1. Porous Medium Site Criteria (Bervig and Pinker 1979). . . . . . 14

2. Characteristics of Prototype System at Texas

A\&M University. ................ 38

3. Physical Characteristics of the Auburn University Aquifer . . . 39

4. Media Storage Field (Henderson County, Illinois)

(Randolph et al 1978) ................. 53

5. Hanson Storage Field (Hopkins County, Kentucky)

(Randolph et al 1978) .............. 54 
POROUS MEDIA EXPERIENCE APPLICABLE TO FIELD EVALUATION FOR

COMPRESSED AIR ENERGY STORAGE

\subsection{INTRODUCTION}

The natural accumulation of 1 iquid and gaseous hydrocarbons in confined anticlinal or domal porous strata makes possible the economic recovery of these resources. The reverse process of storing natural gas within these stratigraphic traps has found widespread acceptance and is well understood. Storage of other gases such as air, hydrogen, and helium is also under consideration because of the regional availability of these low cost natural containments. The storage of compressed air in porous media reservoirs is being investigated as a technique to convert lower cost off-peak base load electricity into mechanical energy for subsequent reconversion during high demand periods. In addition, dissolved salt and mined hard rock caverns are being examined for this potential application. In the porous medium concept, an air bubble would be generated within an aquifer by delivery of air at a pressure higher than the hydrostatic discovery head so that a volume of water equal to the volume of compressed air would be displaced from the nearwell region. Subsequent expansion of the air mass through a conventional combustion turbine-generator would provide an increment of electrical energy above base load output to meet peak demand. Figure 1 illustrates this concept.

In the first demonstration, air will probably be injected at a temperature close to that of the natural reservoir. This will require cooling to remove the heat of compression (reducing the injected air temperature from about $350^{\circ} \mathrm{C}$ to below $100^{\circ} \mathrm{C}$ ). On the generation side of the cycle, a fossil-fueled combustion turbine will be required to reheat the compressed air. However, possible storage at elevated temperatures is of great interest because of rising prices of hydrocarbon fuel, 


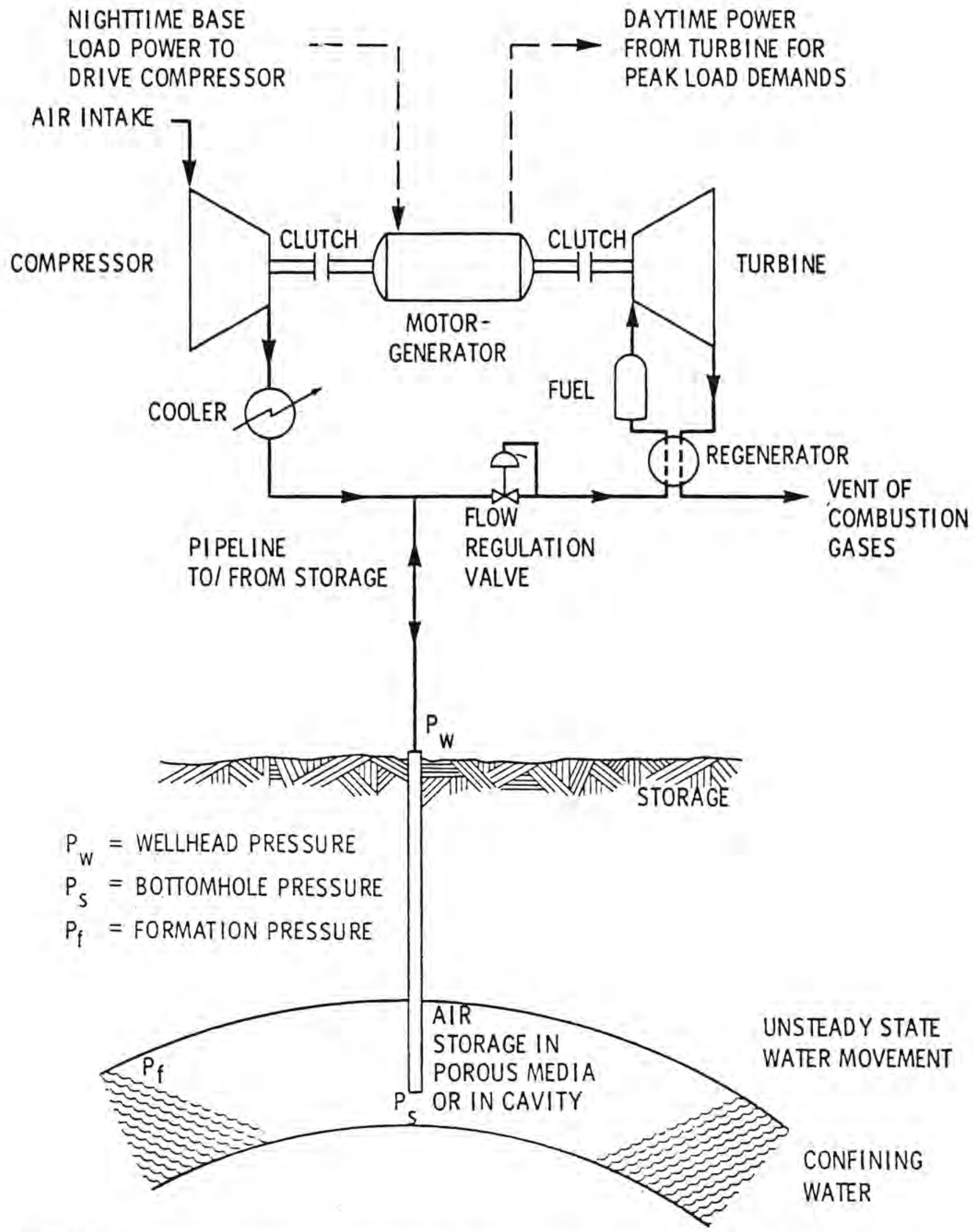

FIGURE 1. Flow Diagram for Compressed Air Storage Plant (Stottlemyre et a) 1979) 
decreasing availability of fuel, governmental restrictions on use of oil and natural gas for electric generation, and the necessity to dehydrate the near-wellbore air storage zone fairly rapidly (Stottlemyre et al 1979).

Most of the uncertainties associated with this storage concept concern the subsurface reservoir and the injection-delivery well system. This report is directed at existing and projected geological experience relevant to storage of compressed air in aquifers.

Although most of the experience derived from natural gas storage can be applied to aquifer compressed air storage, several differences exist between the two systems (Weinstein et al 1978). The storage of air for CAES involves daily or weekly, rather than seasonal, cycling. Air has at least twice the viscosity of natural gas; and air storage at elevated temperatures may be desirable. Frequent pressure, temperature, and humidity cycles may have detrimental impacts on the aquifer matrix. In addition, the aerobic subsurface environment produced by air storage may cause formation problems by oxidation of inorganic and organic substances.

Aquifers are suitable sites for compressed air storage because of low construction costs and widespread availability (Weinstein et al 1978). The storage volume of interest consists of interconnecting pores, microcracks, channelways, permeable bedding planes, and joints which characterize the porous medium. An impermeable caprock and some form of structural trap is required to contain the air. Target aquifers must be deep enough to provide pressure suitable for turbine operation. A variety of operating pressures, and consequently, variable turbomachinery can be accommodated by varying the injection/discharge well operating characteristics (e.g., varying well numbers and diameters). Figure 2 shows potential areas for aquifer storage in the United States. The marine formations of the Midwest are primary targets for aquifer CAES systems. 


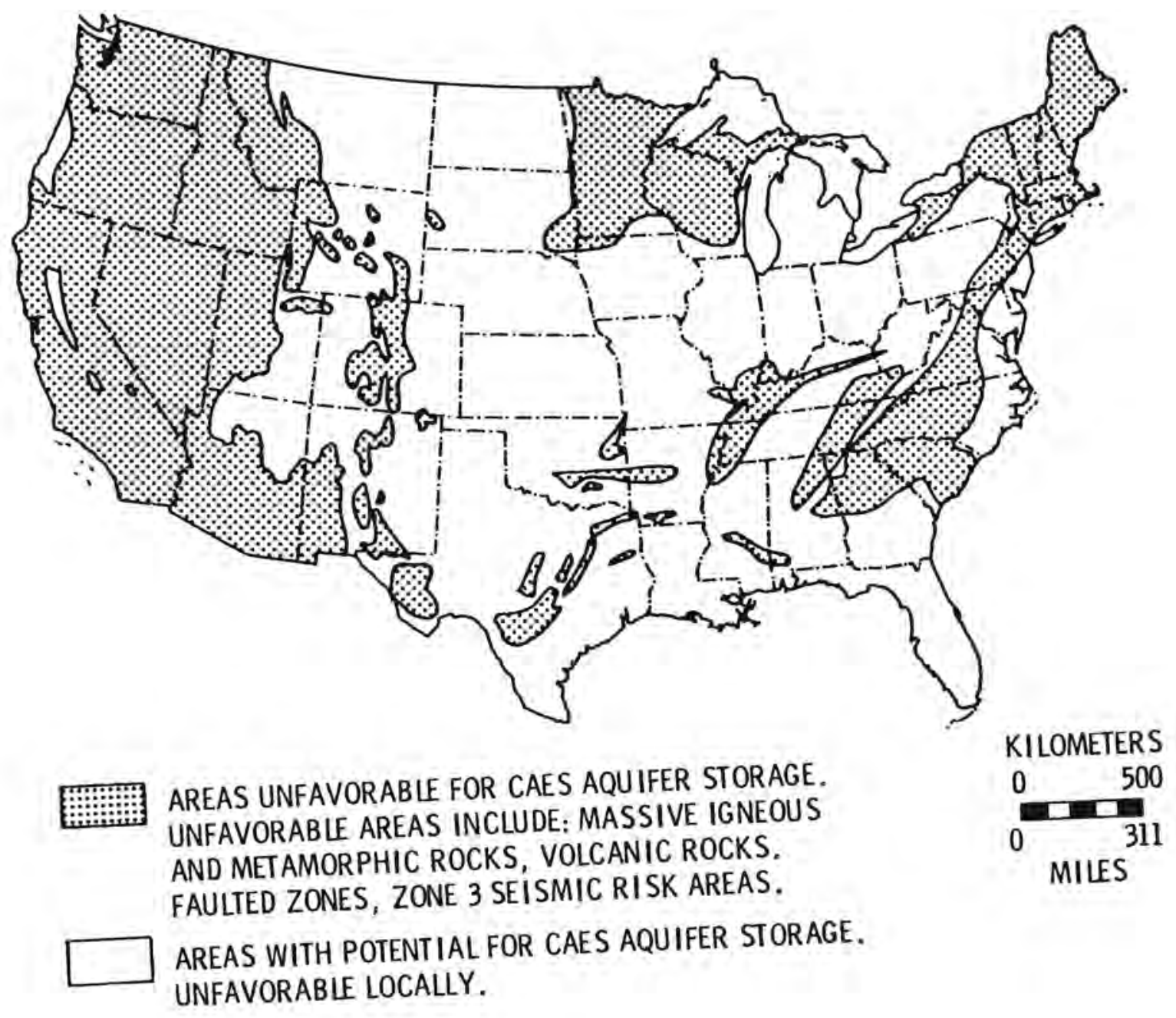

FIGURE 2. Areas Generally Favorable for CAES in Aquifers (Stottlemyre and Loscutoff 1979) 
Site exploration and selection will involve drilling programs to evaluate geologic structure, stratigraphy, petrology and hydrology. Geophysical, geochemical and rock mechanical characteristics of the storage and barrier horizons must be evaluated under the cyclic conditions of temperature, pressure and air/water exposure. Of considerable importance are: the time dependencies of aquifer permeability, caprock impermeability and strength, thermo-mechanical stability of reservoir and caprock, and dehydration near the wellbore; well casing and completion cement integrity; hydrologic isolation from potable water sources; and absence of deleterious air/water/rock chemical and physical reactions.

Research is being performed at Pacific Northwest Laboratory and subcontractor laboratories to establish design and stability criteria for each geologic mode of compressed air energy storage, i.e., porous media, solutioned salt cavern and mined hard rock cavern. It is expected that the final criteria will assure successful cyclical storage over the design life of each mode. Each study consists of four phases: 1) state-of-the-art survey, 2) analytical modeling, 3) laboratory examination, and 4) field testing. This report constitutes the initial task of Phase 4 in the porous media study: Survey existing experience applicable to field studies in compressed air energy storage. 


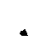




\subsection{CONCLUSIONS AND RECOMMENDATIONS}

Porous media field experience in areas surveyed, such as natural gas storage, is indispensable to operation of an aquifer compressed air energy storage (CAES) system. There is, however, little experience in the injection of air at high temperature and pressure with frequent cycling. While theoretical and laboratory studies are valuable, testing must be performed in the field to evaluate the effects of this air on an aquifer before actual compressed air storage can be widely utilized.

The basic recommendations for compressed air field studies as a result of aquifer CAES preliminary design are as follows:

- The ultimate answers concerning compressed air storage in porous media can be obtained only from field tests involving compressed air injection, well field monitoring, and compressed air recovery (Stottlemyre et al 1979). Cyclic variations in temperature, pressure and humidity must duplicate actual operating conditions.

- The porosity, permeability, volume, and closure of the reservoir must be sufficient to receive, store and deliver an air mass of sufficient quantity within acceptable time intervals. Field testing will be required to establish permeability, thickness and areal extent of the aquifer and structure.

- Maximum injection pressure should not exceed $18.1 \mathrm{kPa} / \mathrm{m}(0.80$ $\mathrm{psi} / \mathrm{ft}$ ) of vertical depth to prevent fracturing.

- The caprock should have a threshold pressure greater than twice the difference between charging and discovery pressures.

- Injection air temperature should not be high enough to cause in situ vaporization of interstitial water.

- Injection of unsaturated air at moderate injection temperatures, e.g., $66^{\circ} \mathrm{C}\left(150^{\circ} \mathrm{F}\right)$, will ensure displacement of most near-wellbore liquid phase water. (Water structurally isolated within non-communicating pores will not be displaced.) 
- In situ evaporation of residual formation water with undersaturated air appears to be the favored mechanism for dehydration of the near-wellbore region.

- Numerical analysis shows that the work required for water displacement and air injection/withdrawal increases dramatically for permeabilities below $300 \mathrm{md}$.

Conclusions about the CAES site selection process include:

- Field planning must include interfaces with locar, state, and federal governments as required to assure compliance with regulations governing subterranean and surface land use for compressed air storage and utilization.

- Fluid ownership rights may take priority over rights to store compressed air by displacement of ground water.

- Prior practices and regulations for hydrocarbons can help establish air storage rights.

- CAES reservoir site selection is determined by geological/technical feasibility, economics of location, and environmental/institutional acceptability.

- Aquifer storage characteristics and availability can be extrapolated from natural gas storage experiences, al though permeability requirements and environmental considerations are slightly different for compressed air storage.

- The CAES reservoir should not be developed close to a seismically active fault or fault zone.

Related experience in porous media will aid CAES field studies as shown in the following conclusions:

- Natural gas aquifer storage experience offers technology in areas of site searching and exploration, reservoir testing, caprock evaluation, storage pressure calculation, and storage development and monitoring. Geological and technical data necessary in CAES 
system development are evaluated for natural gas storage systems (1 isted in Section 3.2.1.5). The important differences between air and natural gas storage systems are the cycling schedules and chemical/physical air/gas differences.

- Particular sites in depleted petroleum or natural gas fields may be disqualified for CAES because of the potential combustion hazard. Utilization of these fields has been recommended in California but excluded in Kansas. The effects of more frequent cycling and the potential reaction of hydrocarbons with oxygen at its partial pressure of compression should be evaluated for the temperature range of interest.

- Highly developed monitoring programs in natural gas storage have set the groundwork for CAES. Shorter cycling periods and higher loss tolerance (economically and environmentally) will probably result in less stringent monitoring requirements for CAES.

- Technology may be transferable from thermal energy storage operations in areas of formation characterization and aquifer utilization. Preliminary aquifer considerations developed in thermal energy storage research can aid in CAES development.

- Geothermal technology used in site evaluation, reservoir and well development, and well field monitoring may be applicable to CAES aquifer exploitation. Geophysical methods with potential value for site location include electrical resistivity, seismic reflection, gravimetric surveying, and exploratory well logging. Reservoir development costs may be reduced by using advanced drilling tools and advanced casing/cementing methods. Well field monitoring tools could include the following: seismographic networks, high temperaturehigh pressure well logging devices, and standard gravimetric surveying. 


\subsection{POROUS MEDIA FIELD EXPERIENCE}

\subsection{COMPRESSED AIR ENERGY STORAGE EXPERIENCE}

CAES field experience in porous media is very limited. Significant progress has been made only in field evaluation and site selection as shown in the three examples reported in this section. Actual field implementation is not known at this time.

The process of site selection for compressed air energy storage is very complex. Although the environmental and siting aspects of the surface plant for a CAES system have many similarities with a gas turbine power plant (Hobson et al 1979), the location of the CAES plant is even more constrained because siting is required above a suitable formation. Figure 2 illustrates areas of the continental United States that are considered favorable for aquifer storage of compressed air (Stottlemyre and Loscutoff 1979). A permeable sandstone is overlain by a relatively impermeable caprock such as shale or dolomite. Overlying the caprock may be other alternating aquifer/aquiclude systems, an unconfined saturated zone, a partially saturated (vadose) zone, and finally the ground surface. Such a stratigraphic system, penetrated with tens or hundreds of injection/ withdrawal wells, comprises the setting against which the environmental assessment must be conducted.

\subsubsection{California}

A study by Acres American Incorporated (Hobson et al 1978) in association with Woodward-Clyde Consultants and Unized Technologies Research Center was conducted for the California Energy Commission to report the feasibility of utilizing CAES in California for peak shaving in electric utility systems. Storage in porous media was included. A conceptual plant design was prepared for operation in a depleted gas field. An inventory of suitable sites was made along with other elements of the feasibility study. 'Ranges of depth and volume needed were calculated from the theoretical plant operating conditions. Other criteria included limits on air leakage, pressure maintenance, and air pressure loss. The site selection process discussed in the report is explained below. 
Geologic basemaps were overlaid with broad exclusion areas such as national forests, state parks, and seismically active areas. A field-byfield screening was made of all existing producing and depleted oil and gas fields in California. Saline aquifers associated with oil and gas fields were identified in addition to saline aquifers contained in marine sedimentary bedrock areas and alluvial covered marine sedimentary basins.

The foregoing procedures resulted in the identification of a large number of candidate sites for air storage in porous media(a). Examination of the available data on these sites indicated whether or not the sites met the established criteria, were located within exclusion areas, or were economically feasible based upon a sensitivity analysis to determine limiting cost and performance parameters. Many of the geologically suitable areas were eliminated due to the excessive cost of constructing transmission lines and roads to the sites. The saline aquifers that were not associated with oil or gas containment structures were also eliminated on the basis that the feasibility of utilizing such a formation for air storage has yet to be determined. Those sites remaining were assessed for geologic suitability and then reviewed for non-technical items such as air quality, population density and biota.

The report concluded that drilling and testing to the depth of the formation is the only way to confirm the feasibility of a site. Recommendations were made for field tests of air injection and recovery before CAES utilization by the utilities.

\section{1 .2 Kansas}

An assessment of compressed air energy storage (Bervig and Pinker 1979) was done for the Kansas Utility System by Black \& Veatch, Consulting Engineers of Kansas City, under the management of the Electric Power Research Institute. Site selection criteria and procedures were established

(a) This finding contrasts with the negative regional geologic evaluation for California shown in Figure 2. 
as a part of the study. The studies done on power requirements and economic evaluations are not addressed in this report. Site selection criteria were divided into three categories: technical, economic and environmental. The technical criteria were further subdivided into the categories of surface plant and air reservoir. (a) A power requirement analysis of a porous medium reservoir resulted in the specific values given in Table 1. Some of these are explained in the following text.

Bervig and Pinker (1979) stated that the stability of the reservoir is a function of geomechanical properties and the depth of the geologic stratum in which the air reservoir is formed. The minimum depth of the reservoir is determined by the minimum thickness of overlying strata and overburden required to safely contain the maximum pressure anticipated in the air reservoir. If the pressure in the air reservoir exceeds the geostatic pressure, the overlying strata may fracture or part along bedding planes, allow air to escape, and possibly displace ground water or damage surface structures. To prevent this and provide a reasonable margin of safety, the maximum operating pressure of the air reservoir with respect to geostatic pressure should not exceed $11.3 \mathrm{kPa} / \mathrm{m}(500$ psi/1,000 ft) of depth. If the differential pressure between the pressure in the air reservoir and the pressure in the caprock exceeds the caprock threshold pressure, air will displace the connate fluids, diffuse through the caprock, and leak from the air reservoir. To provide adequate assurance that the caprock will not leak, its threshold pressure should be at least twice the maximum differential pressure, or a minimum of 4.14 $\mathrm{MPa}$ (600 psi). Therefore, the caprock permeability should be less than $10^{-5}$ millidarcies as shown in Figure 3 .

The study predicts that a caprock of an inverted saucer shape would form a suitable reservoir in the porous medium and prevent vertical and

\footnotetext{
(a) Details on the site selection procedure may be seen in the article referenced (Bervig and Pinker 1979). The final report (Wallace and Bervig 1978) on this project includes a site development schedule including exploratory drilling, aquifer and geophysical tests and laboratory testing of cores for engineering properties related to surface plant design.
} 
lateral migration of the air. A minimum permeability of 200 millidarcies would provide for the required mass flows of air for the power requirements of a reference plant. As a final criterion, depleted $0 i 1$ and gas reservoirs were not considered in this study because of the danger of ignition and/or explosion in the reservoir when air is mixed with petroleum at high pressures.

\subsubsection{Strata Power of Indiana}

Strata Power of Indiana (Lang 1975) was a corporation formed with the principle intent of developing underground compressed air storage for electric power generation and other industrial purposes. The company acquired storage rights at five locations within the state. The CalcuttaCarbon field reservoir in west central Indiana was used as an example from which a detailed analysis of costs and benefits was made. The following text is taken from portions of this study pertaining to field evaluation for compressed air storage.

The study brought up some general considerations to be made for storage space acquisitions. In strata where fluids fill the natural pore spaces, consideration must be given not only to the rights for use of the space but rights of ownership and economic value of these stored fluids. Laws and regulations pertaining to the fluids affect and may take priority over storage rights. Such spaces may be filled with potable water, oil, gas, or combinations of these. Even if commercial hydrocarbons are absent or not proven, rights to explore for such in any given strata may preclude any further development for storage space. It was also noted that prior practices, extant laws and regulations for fugacious fluids and hydrocarbons are not necessarily a deterrent to underground air storage but can expedite and facilitate establishment, acquisition and definition of air storage rights. Standard leases, common for oil and gas, cover rights for "gas" storage. If stated in the broad sense, these leases may be extended to include air, inert, or synthetic gas. Some leases and state regulations specify air as one of 
TABLE 1. POROUS MEDIUM SITE CRITERIA (BERVIG AND PINKER 1979)

Technical, Surface Plant

Area

Minimum of 40 continuous acres

$(0.162 \mathrm{sq} \mathrm{km})$

Relief

Vary less than $50 \mathrm{ft}(15.2 \mathrm{~m})$ over 40 acres $(0.162 \mathrm{sq} \mathrm{km})$

Geologic Hazards

No landslides, subsidence, earthquakes, or flooding

Plant

150 to $200 \mathrm{MW}$ power generation
Technical, Air Reservoir

Stratum

Sandstone or carbonate rocks

containing water or brine; greater than $10 \%$ porosity and $200 \mathrm{md}$ permeability

Capacity

$8.50 \times 10^{6} \mathrm{~m}^{3}\left(300 \times 10^{6} \mathrm{ft}^{3}\right)$ minimum

Shape

Inverted saucer with $2: 1 \mathrm{~L} / \mathrm{W}$ ratio, $46 \mathrm{~m}(151 \mathrm{ft})$ of closure, side slopes of $0.2\left(11.3^{\circ} \mathrm{dip}\right)$

Depth Range $229-914 m(751-2998 \mathrm{ft})$

Caprock Permeability

$10^{-5}$ millidarcies

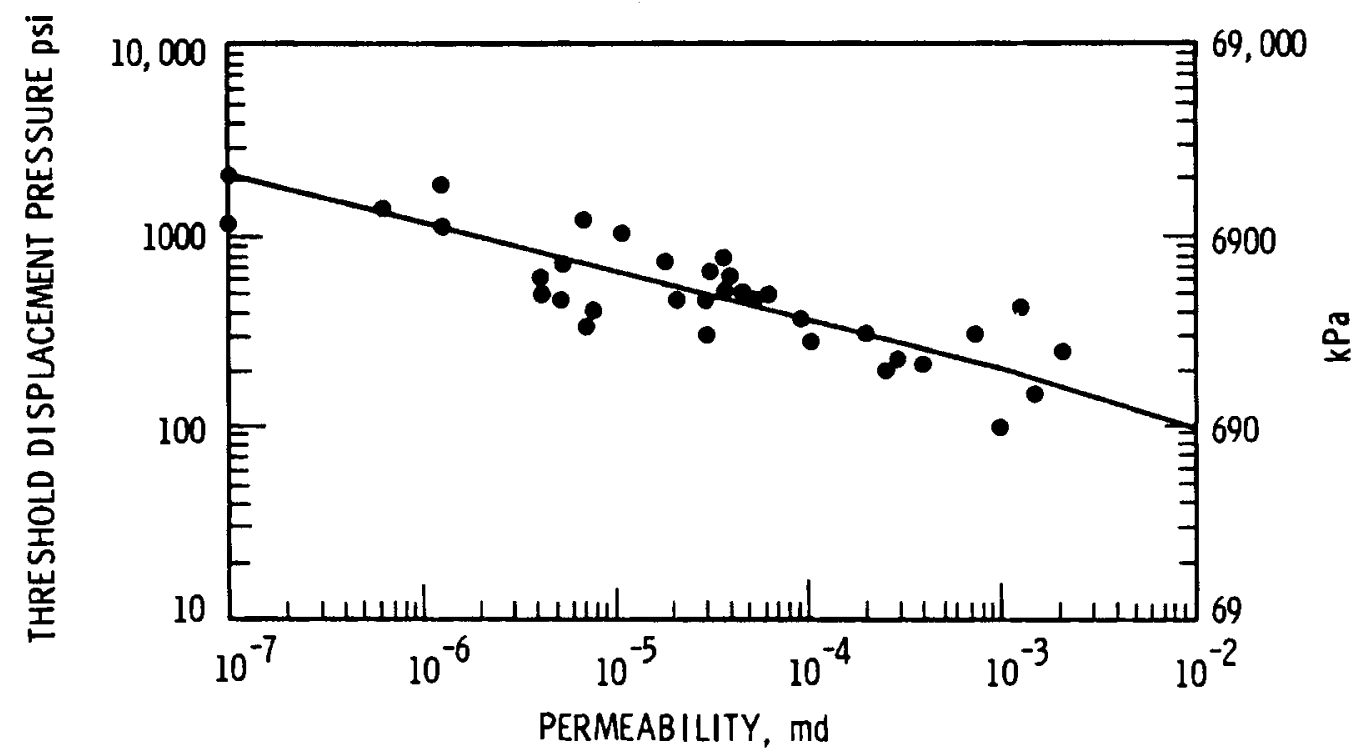

FIGURE 3. Threshold Pressure Versus Permeability (Katz and Lady 1976) 
the gases which may be injected. Compressed air injection, for enhanced oil recovery by repressurizing gas drives, heat emplacement or sustaining in situ combustion, has been used on numerous projects in the Illinois basin.

Research showed that much information concerning aquifer storage characteristics and availability can be extrapolated from natural gas storage experience, although safety and environmental considerations for compressed air storage are considerably different (Lang 1975). Leakage losses can be tolerated for air storage which are many times higher than the acceptable limits for natural gas. Some reservoirs, therefore, can be acceptable for compressed air which are unacceptable for natural gas.

Lang (1975) reports that sixteen reef-type storage structures, such as the one shown in Figure 4, were developed for natural gas in southwestern Indiana between 1960 and 1975. One such storage area, the CalcuttaCarbon field, is a reef complex comprised of several small highs and a closure of 9 to $12 \mathrm{~m}(29.5$ to $39.4 \mathrm{ft})$. The reef is Silurian in age but the actual storage zone is in the Middle Devonian North Vernon formation near the top of a thick and porous sequence of carbonate strata. The depth is $381 \mathrm{~m}(1250 \mathrm{ft})$ and the thickness of the storage zone where the wells are completed is $3 \mathrm{~m}(9.8 \mathrm{ft})$. The porosity varies from 15 to $20 \%$ and the hydrostatic pressure is $3.2 \mathrm{MPa}(460 \mathrm{psi})$. The total storage volume is estimated to be in the order of 85 million $\mathrm{m}^{3}$ ( 3 billion standard cubic $\mathrm{ft}$ ). Other porous zones are available to increase the storage capacity. The caprock is a $30 \mathrm{~m}$ (98.4 ft) thick section of New Albany Shale which has shown excellent confinement for all gas storage projects in the area.

Measurements of permeability and porosity on cored porous carbonate storage strata yielded unreliable results. Pump testing was performed on the Calcutta-Carbon field by perforating 4 wells in the storage zone, pumping one well and observing the drawdown of the water levels against time in the observation wells. The results conform to the mathematical model of a non-leaky artesian system with close correlation from well to 


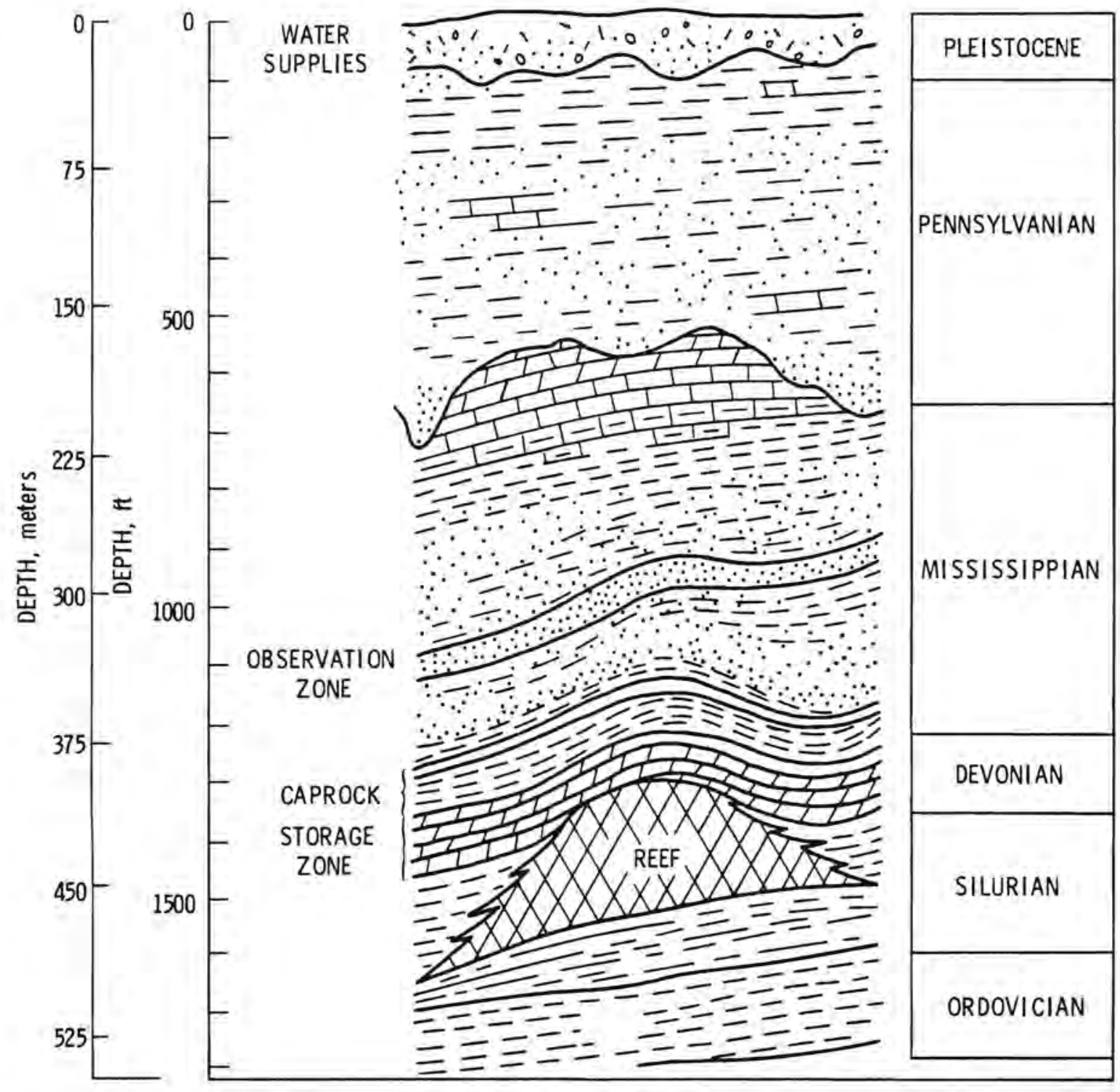

FIGURE 4. Geologic Section Showing Reef and Drape Structure in the Calcutta Carbon Field (Lang 1975) 
well. The calculation of permeability by the Theis solution for the pumping wel1 was 6,635 md with 5,924, 7407 and 6001 md calculated for the observation wells. Observation wells completed into two sandstone aquifers above the New Albany Shale showed no response to the pump testing, verifying that they are hydrologically isolated from the storage zones below. This is further evidenced by the fact that the Carper Sandstone, about $61 \mathrm{~m}(200 \mathrm{ft})$ above the storage zone, contains salt water with $30,000 \mathrm{ppm}$ chlorides whereas the storage zone has only 2700 ppm chlorides.

Natural gas was injected and withdrawn at the site to further verify adequacy of containment. Fluid level measurements on each well confirmed the absolute tightness of the storage strata and provided a technical data basis for mathematical modeling of the reservoir for air storage purposes.

Cores from the storage, caprock and reef zones were subjected to intensive rock analysis. All of the wells were logged with a wide spectrum of geophysical logging normally including sonic, gamma rayneutron, induction-electric, microlog with caliper, neutron, cement bond and continuous dip meter. In addition, each water well in the area was sampled and chemically analyzed and the results were filed with the Indiana Board of Health for future reference in case of controversy concerning ground water alteration resulting from gas storage operations. No leakage or ground-water interference has resulted over the investigation period.

Lang (1975) explained that the deliverability expectation per well, in the example storage field, is a function of reservoir properties, formation pressure, the operating differential, the amount of air cushion and completion conditions of each well. The wells in the gas storage field were not completed for maximum deliverability, as would be necessary for air storage. Optimum completion of about four $30.48 \mathrm{~cm}(12 \mathrm{in})$ wells or seven $21.91 \mathrm{~cm}(8-5 / 8 \mathrm{in})$ wells would be required to sustain a $150 \mathrm{MW}$ plant. This small number of wells would minimize surface air gathering system requirements and frictional losses. 
It was concluded that demonstration and development of the compressed air storage concept can proceed rapidly if full advantage is taken of pretested reservoirs such as the Calcutta-Carbon field.

\subsubsection{Applications to CAES Field Development}

CAES in porous media will benefit greatly from previous field evaluations. The feasibility study in California resulted in two conclusions. First, drilling and testing to the depth of the formation must be done to confirm the usability of a site. Second, field tests of air injection and recovery are necessary before CAES utilization by the utilities.

The assessment in Kansas focused on reservoir design criteria. Depleted $0 i 1$ and gas reservoirs were excluded due to the danger of ignition and/or explosion in the reservoir when air and petroleum are mixed at high pressures.

Strata Power of Indiana took note of legal issues and available natural gas storage information that can contribute to CAES site searching and reservoir development. It was concluded that CAES development will proceed rapidly if full advantage is taken of pretested reservoirs.

\subsection{RELATED EXPERIENCE}

Porous media field experience in other storage technologies will enhance compressed air energy storage research and development. Four areas are addressed in this section, each with a varying depth of experience in field evaluation for storage purposes.

\subsubsection{Natura1 Gas Storage}

Some thirty-five years of experience in handling underground storage reservoirs has been accumulated by the natural gas industry (Katz and Lady 1976). Underground gas storage is accomplished when gas is transferred from producing fields to other reservoirs, usually closer to market areas, where it is stored until needed to supplement other natural gas supplies in meeting market requirements. 
In 1915 the first recorded experiment in storing gas underground was successfully accomplished in Welland County, Ontario, Canada (Committee on Underground Gas Storage 1975). Several old wells in a partially depleted gas field were reconditioned. Gas was injected into the field, pressure built up, and gas was withdrawn the following winter to meet peak requirements. Additional field experience showed that gas injected into depleted sands could be completely recovered. In 1946, the Doe Run Field development in Meade County, Kentucky showed the feasibility of using water sand (aquifers) for gas storage. Now more than 50 aquifer storage sites exist in the United States.

The basic knowledge of fluid containment in the earth and its transmission through wells is contained in $0 i 1$ and gas industry experience (Katz and Lady 1976). Specialized knowledge regarding underground storage of natural gas, developed by the American Gas Association, has been published. Basic to this concept is geologic knowledge much of which was developed by the petroleum industry and published by the American Association of Petroleum Geologists. New technological developments center around aquifer storage (Katz and Witherspoon). Gas has also been stored successfully in an almost horizontal sand stratum. New methods of evaluating caprock layers include water pumping tests in the field and threshold displacement pressure measurements on core samples in the laboratory.

\subsubsection{Storage Reservoir}

The underground storage reservoir in most natural gas storage fields consists of the connected pores in a rock such as in sandstone or the pores in vugular or porous limestones and/or domomites (Katz and Lady 1976). Above the reservoir formation is a caprock, structurally sound, porous, but nearly impermeable saturated rock. The gas is trapped beneath the caprock and above water within the reservoir rock as illustrated in Figure 5. Buoyancy prevents downward migration of gas. The term "aquifer storage" is used to describe gas reservoirs which have been created within an aquifer not hitherto containing gas. Four important characteristics of an underground aquifer storage field are: 1) a shape 


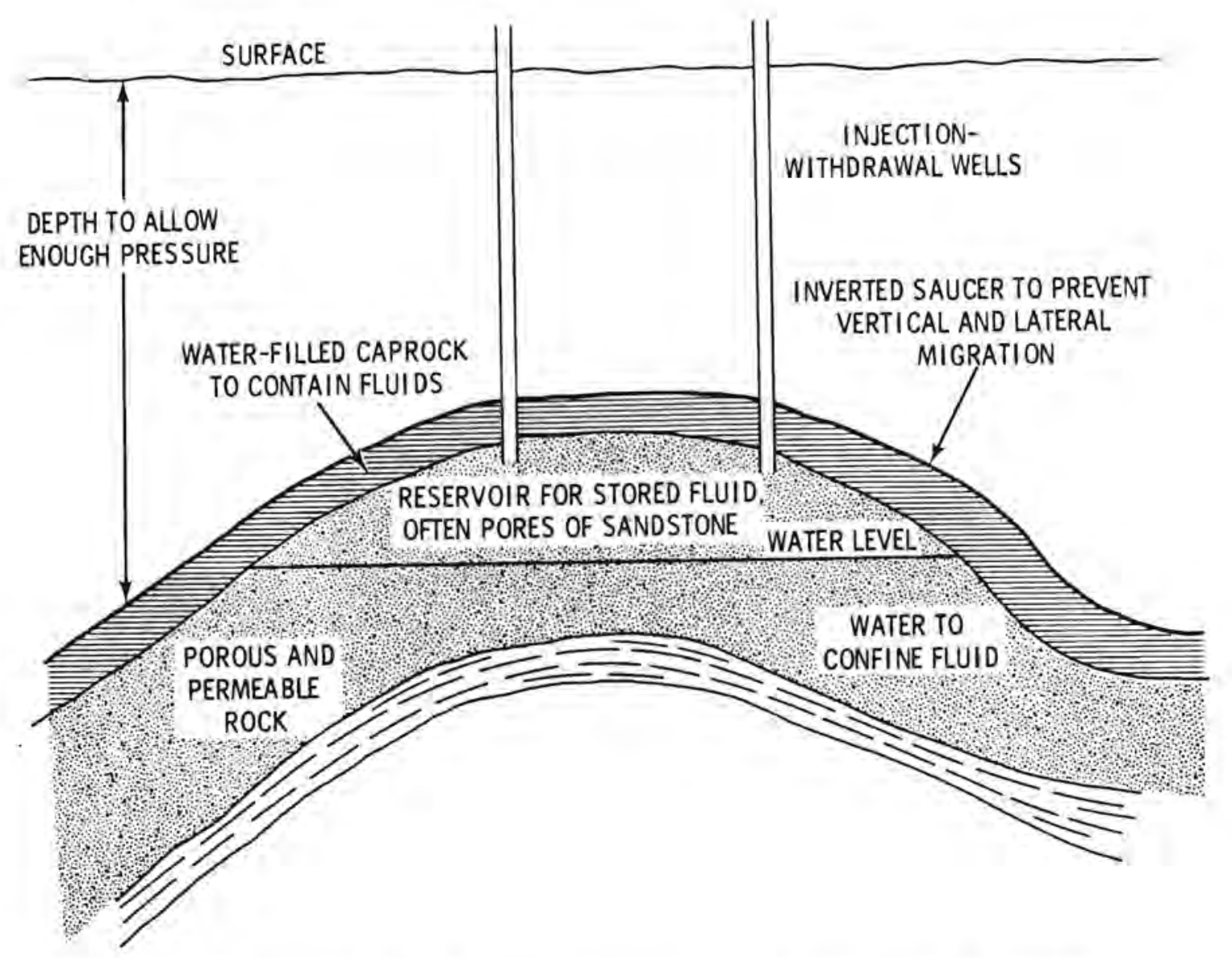

FIGURE 5. A Porous Medium Storage Container (Katz and Lady 1976)

or closure to contain the injected gas, 2) a porous medium containing enough pore space to contain the gas and enough permeability to permit it to flow from the wellbore to the surrounding porous bed, 3) a caprock over the storage zone low enough in permeability and with a threshold pressure sufficient to confine the stored gas within the intended horizon, and 4) a depth such that the hydraulic pressure gradient from the water table to the storage zone gives the desired pressure level for underground storage. Permeability and depth of formation are discussed in the following paragraphs.

The in situ permeability of the porous medium may not be the same as the permeability of core taken from wells (Katz and Lady 1976). A few fractures within the reservoir or variations of permeability in various layers can cause much greater water movement than predicted. 
One way to measure reservoir uniformity and in situ permeability is to run a pump test in which water is produced from one well in the aquifer and the water levels are measured in other wells at varying distances and directions from the pumping well. The water level drawdowns and the rates of recovery can be used to predict the in situ permeabilities between the pumping well and the other wells. The results of a pump test at Garfield in northern Illinois, show that wells some $300 \mathrm{~m}$ $(984 \mathrm{ft}$ ) away may have a $13.7 \mathrm{~m}(45 \mathrm{ft})$ drawdown whereas wells $2439 \mathrm{~m}$ $(8,000 \mathrm{ft})$ from the pumping well do not have a noticeable change in water levels. The floats used in measuring water levels are very sensitive and can read differences of $3 \mathrm{~cm}(1.18 \mathrm{in})$. Water levels in open wells standing in an undisturbed aquifer will also vary with barometric pressure. More than $50 \%$ of the variation in barometric pressure may be reflected by the water level change. Thus, a decline in barometric pressure of $2.54 \mathrm{~cm}$ ( 1 in) of mercury can cause the water level to rise approximately $18 \mathrm{~cm}$ (7.09 in) (specific gravity of mercury $=13.6$ ). Permeable formations react most quickly to barometric pressure changes, as shown in Figure 6 (Katz and Coats 1968).

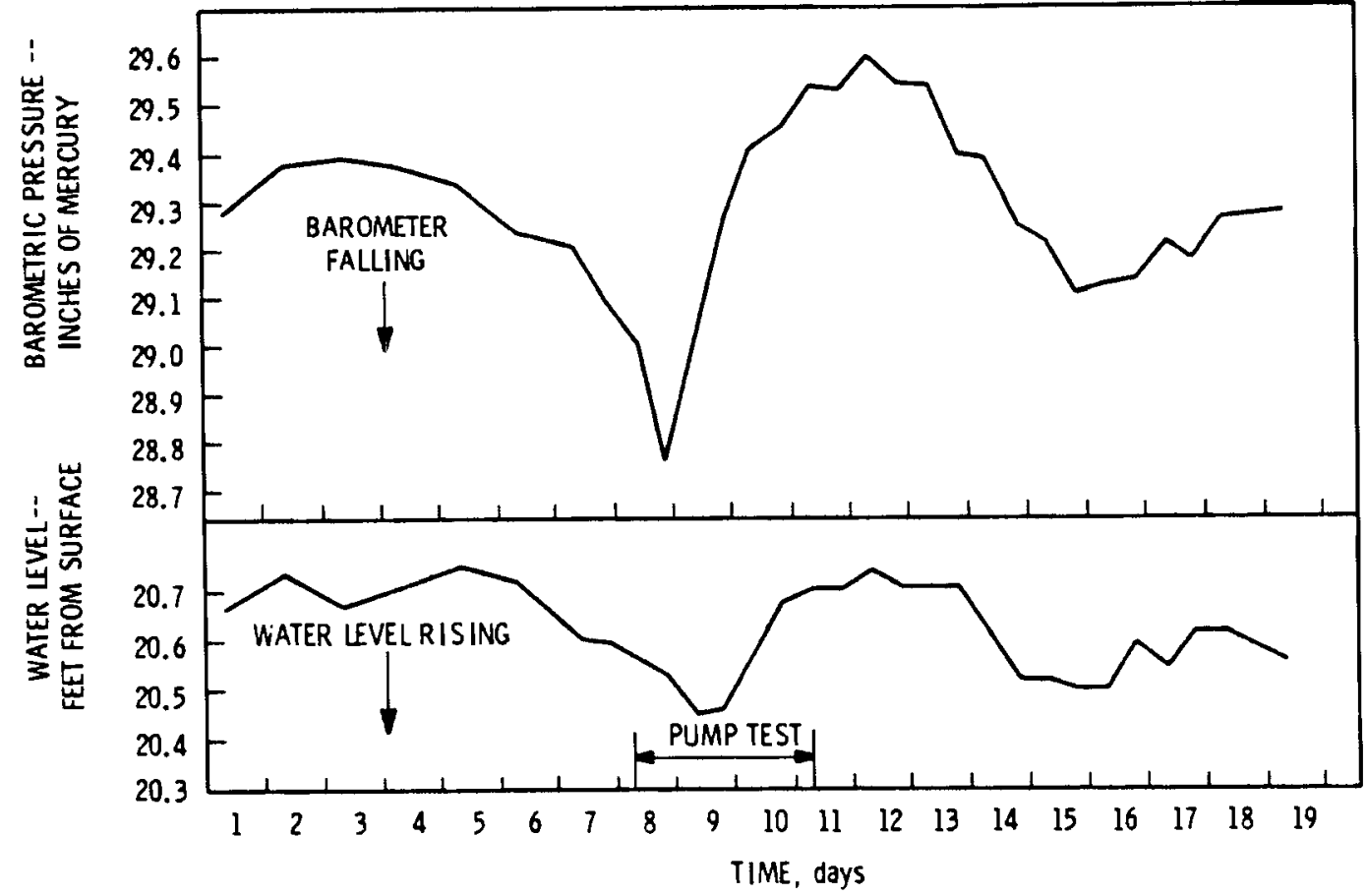

FIGURE 6. Effect of Changes in Barometer Pressure on Water Leve in Open Well on Undisturbed Aquifer (Katz and Coats 1968) 
The reservoir depth determines its hydrostatic pressure. Most natural gas reservoirs are discovered with a pressure gradient from the surface equivalent to that of a like column of water. If the water is fresh, this column will have a pressure-depth gradient of $9.73 \mathrm{kPa} / \mathrm{m}$ $(0.43 \mathrm{psi} / \mathrm{ft})$ of depth. Should the column be fully saturated with salt, it could have a gradient up to $11.76 \mathrm{kPa} / \mathrm{m}(0.52 \mathrm{psi} / \mathrm{ft})$. The pressure required to raise the overburden is about $22.63 \mathrm{kPa} / \mathrm{m}(1 \mathrm{psi} / \mathrm{ft})$ of depth. In some areas gas has been stored at pressures up to $15.84 \mathrm{kPa} / \mathrm{m}$ $(0.7 \mathrm{psi} / \mathrm{ft})$. Water in rock pores will flow when a pressure gradient is present within the system. When gas is injected to create a bubble in the aquifer, a higher injection pressure must be used than the initial aquifer water pressure (discovery pressure) to displace the water away from the wellbore. The injection pressure minus the original aquifer pressure is called a delta pressure (Katz and Lady 1976). In permeable aquifers low delta pressures of 172.5 to $345 \mathrm{kPa}$ ( 25 to $50 \mathrm{psi}$ ) may be used for small projects whereas 690 to $2070 \mathrm{kPa}$ (100 to $300 \mathrm{psi}$ ) are commonly used on large reservoirs such as those contained within the Mt. Simon and St. Peter formations in Illinois and Iowa. Frequently a lower initial delta pressure is used at the start of development with incremental rises through time. Observation wells are used to note the gas bubble pressures during gas injection and hence the delta pressure is continuously indicated. The use of delta pressures for converted oil and gas fields with proven caprocks has increased the storage capacity of such reservoirs to a considerable extent. Figure 7 illustrates the effect of time on pressure distribution when gas displaces water, as during reservoir development. Figure 8 shows how gas may "wafer" initially before gradually merging into a gas bubble due to the rapid displacement of water by the relatively low viscosity gas.

\subsubsection{Closure and Caprock}

The search for a useable structure with adequate closure may be simplified by data from state or federal geologic sources and water well information (Katz and Coats 1968). Shallow core holes drilled to a marker or base rock bed will help to identify a given layer which is 


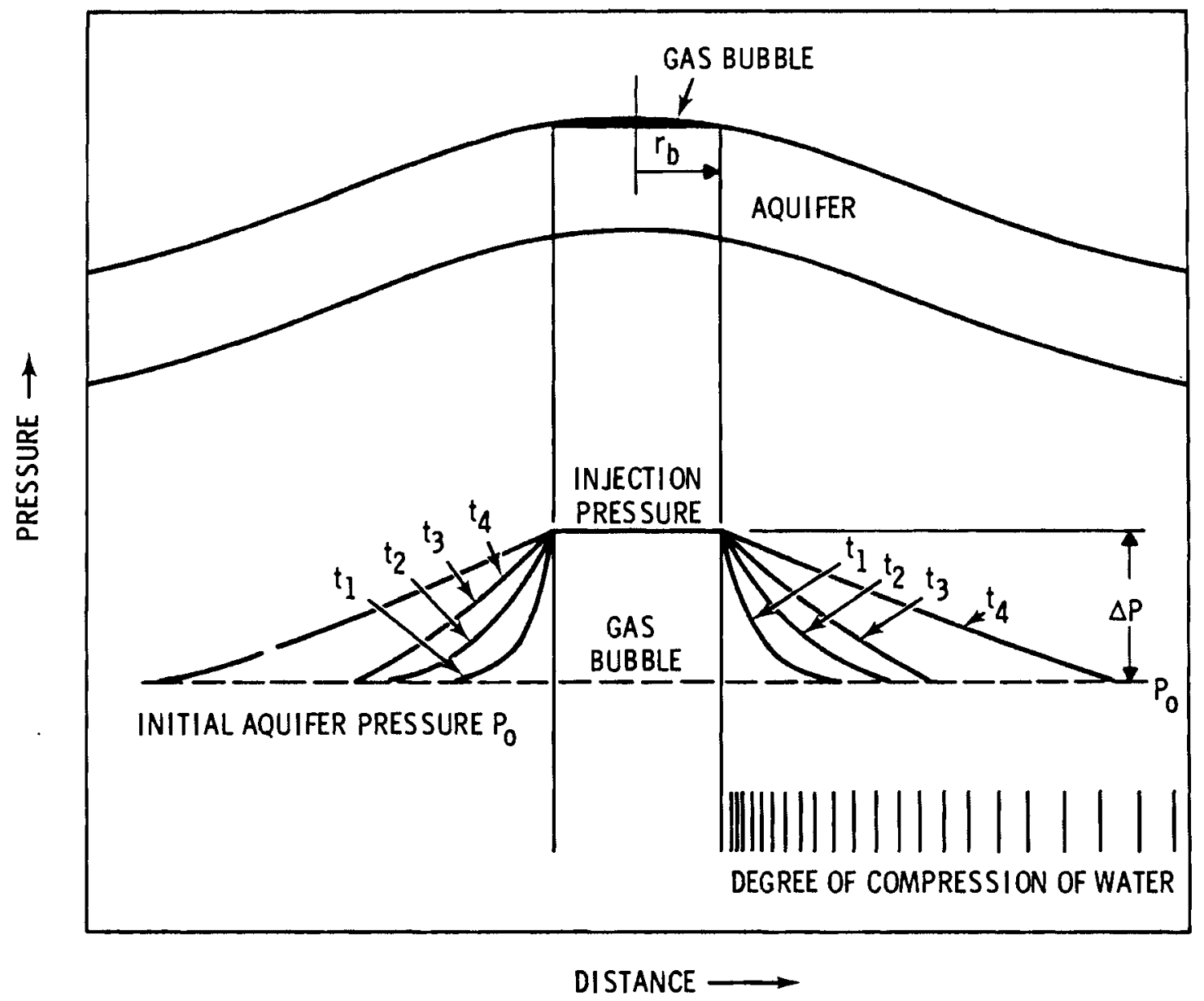

FIGURE 7. Effect of Time on the Pressure Distribution in Aquifers (Katz and Lady 1976)

considered to be symmetrical with the structure. Core holes to depths of 90 to $200 \mathrm{~m}$ ( 295 to $656 \mathrm{ft}$ ) will identify the marker bed and facilitate the mapping of the shallow structure. General knowledge of geology can indicate whether the structure is likely to have greater or less closure with increased depth. A deep well is drilled somewhere near the expected crest to core the intended caprock and storage reservoir formation. Tests are made on the cores to obtain the porosity, permeability, and capillary pressure curves for the storage horizon and the permeability and threshold pressure for the caprock. Favorable information will 


\section{INJECTION WELL}
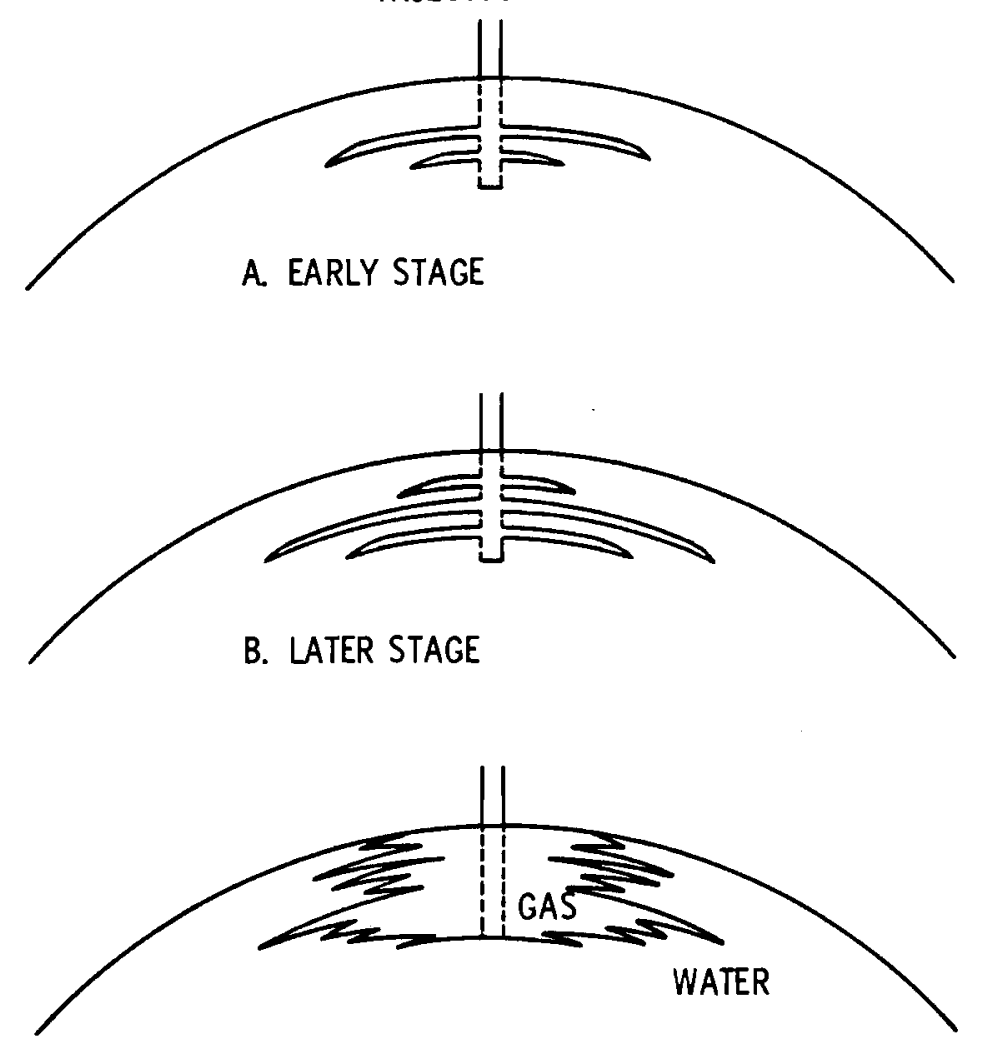

C. STILL LATER WHERE GAS PHASE

MAY BE CONSIDERED TO BE "A BUBBLE"

FIGURE 8. Gas Wafering During Initial Injection in Aquifer (Katz and Lady 1976)

merit the drilling of deep wells to find possible spill points and determine the nature of the interval between the marker bed and the deeper horizons. When 3 or 4 deep wells have been Irilled, sufficient information from this interval may permit development of a structure map keyed to the deeper reservoir horizon.

A sedimentary caprock may have stratigraphic variations such as a lateral "facies" change (Figure 9) which can substantially reduce the apparent closure (Rudd 1979). Two generally accepted methods of caprock evaluation are pump testing and core analysis. These are presented separately, but should be viewed as complementary techniques. 


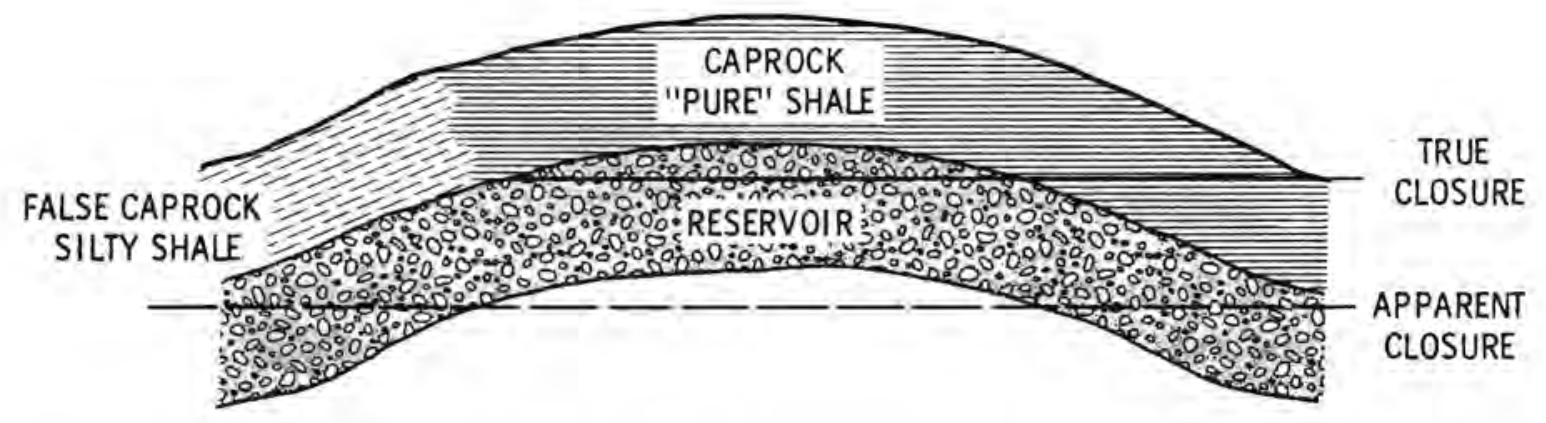

FIGURE 9. Reduction of Effective Closure by Facies Change (Rudd 1979)

Pump testing involves the reduction of pressure beneath the caprock by pumping water from one well while simultaneously observing pressure response, usually in terms of height of water column, that occurs in observation wells completed above the caprock (Figure 10). Pump tests are particularly useful for the determination of gross caprock permeability and the recognition of major features such as faults. Under ideal conditions, such a test may contribute to the evaluation of several hundreds or even thousands of acres. A pump test is most applicable in areas of somewhat restricted permeability where ground-water recharge will not equalize the pressure drop in the reservoir.

Caprock evaluation through the analysis of core samples provides direct physical measurements of caprock parameters. Customarily, this includes determination of permeability, porosity, and threshold pressure. of course, the radius of investigation by core analysis is 1 imited to the diameter of the core and the validity of these data depends upon the degree to which the core is truly representative of the permeative 1ithology. Norma11y, it will be necessary to core analyze the caprock in a number of wells in order to reach reasonable confidence that the data are applicable throughout the storage field.

Core analysis permits the measurement of threshold pressure, the most critical parameter, and can provide very detailed data on a footby-foot basis, permitting identification of the critical zones within 


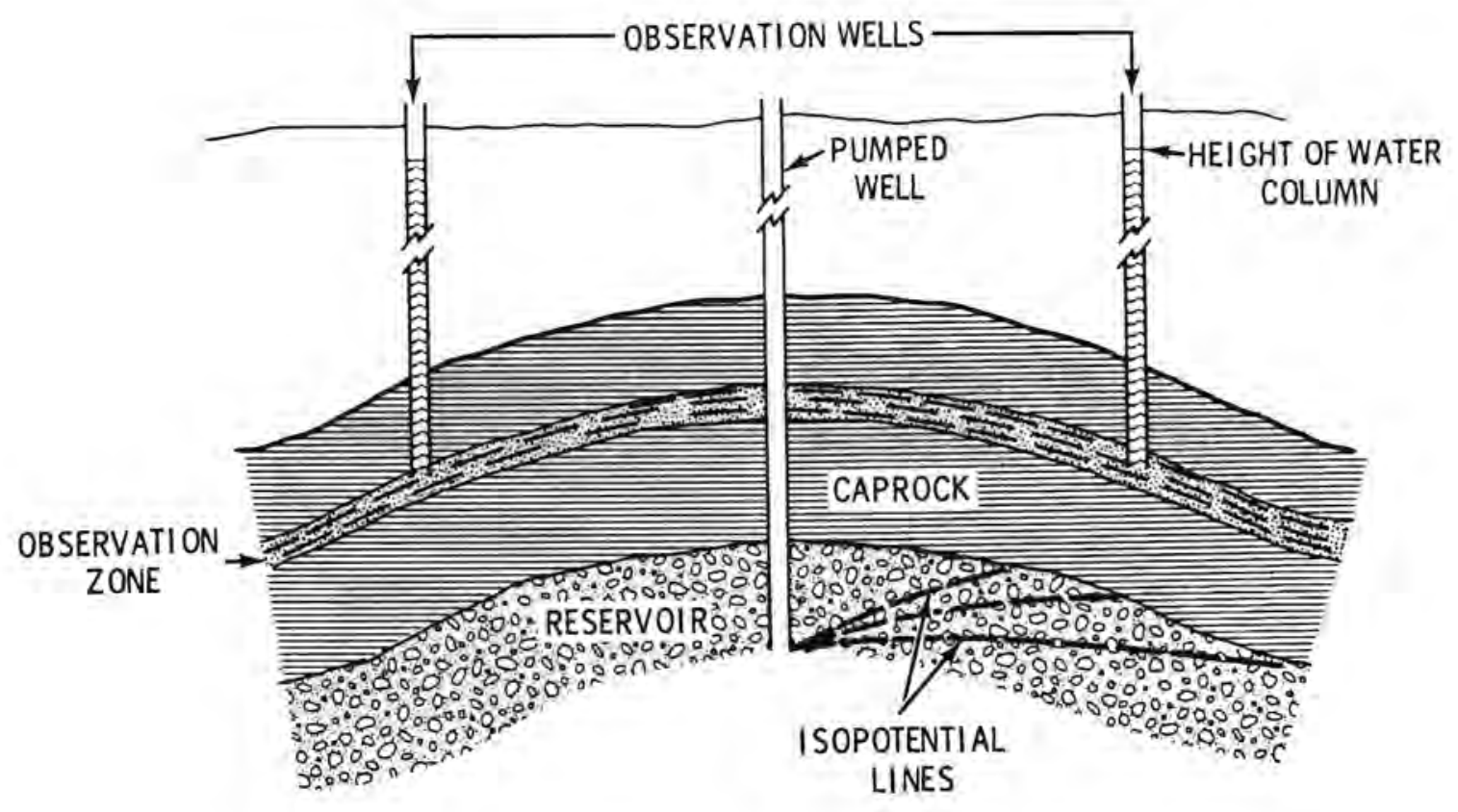

FIGURE 10. Pump Test Evaluation of Caprock (Rudd 1979)

the gross caprock section. However, permeabilities obtained from core analysis are nearly always lower than those obtained by pump test because of secondary permeability which does not influence core samples. The discrepancy may reach an order of magnitude.

Threshold pressure is the maximum pressure differential which can be exerted across a caprock without fluid transmission. Maximum storage pressure, in turn, is the sum of the threshold pressure plus the hydrostatic pressure (above the gas/water interface). Threshold pressure determinations to maximum limits of 5000 to $6600 \mathrm{kPa}$ (725 to $957 \mathrm{psi}$ ) provide a very conservative margin of safety for most purposes. Most samples of relatively pure shale caprocks and many samples of carbonate caprock have threshold pressures which will exceed this value. Experimentally, some specimens of both shale and carbonate caprocks have been tested to a maximum level of $20.7 \mathrm{MPa}(3000 \mathrm{psi})$. On the basis of a limited number of samples, Paleozoic shales from the upper Midwest show threshold pressures below 13.8 MPa (2000 psi), but a few extremely dense limestone samples have threshold pressures in excess of $20.7 \mathrm{MPa}$ (3000 psi). Figure 3 shows 
the relationship between threshold pressure and permeability based upon experimental tests of potential caprocks (Katz and Lady 1976).

Two other so-called methods of caprock evaluation are described as "experience" and "pilot testing" (Rudd 1979). Natural gas storage experience is replete with examples of apparently similar structures in which one field was successful whereas another was not. Experience may provide a basis for cautious optimism, but it certainly does not constitute an adequate caprock evaluation. Pilot tests may be useful to confirm or disprove the existence of suspected gross caprock deficiencies but they cannot in themselves be considered as ul timate proof of reservoir integrity. The ultimate proof of caprock integrity for CAES is gas storage development and successful operation.

\subsubsection{Storage Development and Monitoring}

Gas storage operators will demonstrate well producibility when a sizeable gas bubble has been established (Katz and Lady 1976). Trial flow tests usually pass without incident, with most flow problems due only to water interference. This problem diminishes as the bubble gets thicker and as the near-wellbore sand loses its water by gas displacement and evaporation due to injection with high temperature or unsaturated gas.

A monitored storage system is shown in Figure 11 (Katz and Lady 1976). Movement of gas away from the intended storage area through a spill point is monitored by a peripheral water phase observation well. Such a well would show the presence of gas or a pressure rise to indicate the proximity of encroaching gas. Migration could be caused by the pressure gradient or ground-water movement through the aquifer. Water observation wells above the caprock will indicate gas leakage either by pressure rise or by the presence of gas. The possible source of gases in the shallow and intermediate layers can be caprock leakage or, more likely, imperfect cementing of wells or casing leaks. Because of these possibilities, even the shallow water sands need monitoring. 


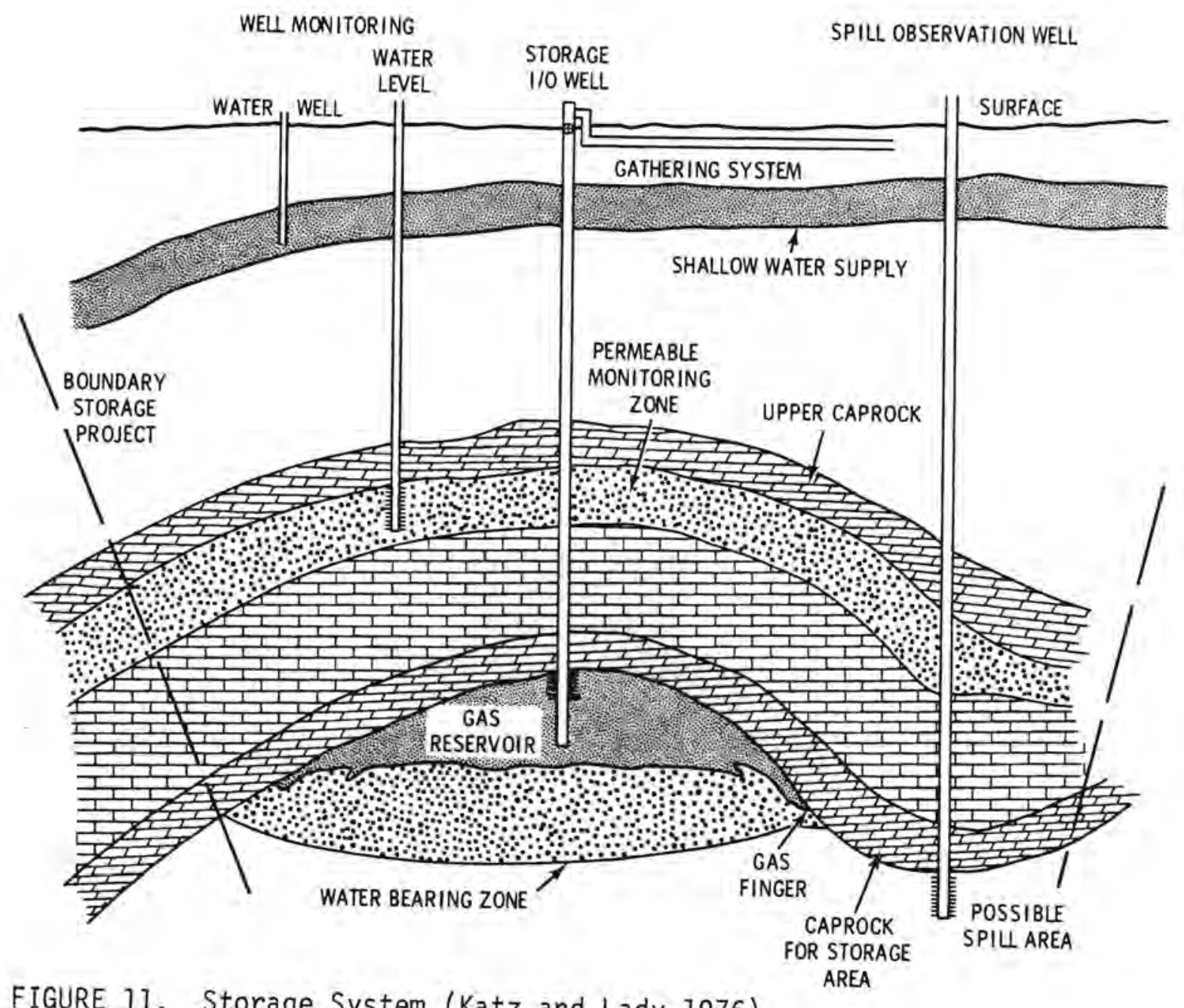

FIGURE 11. Storage System (Katz and Lady 1976)

Experience has shown that the earth between the caprock above the storage bubble and the surface should be expected to receive at least detectable amounts of stored gas over the life of the storage project. However, natural gas is not likely to harm potable water, and beyond the possibility of combustion at the surface, gas is not harmful in low concentrations. Much of the earth already contains combustible gas (methane) as revealed in water samples taken prior to development of storage projects.

A number of sensitive instruments have been developed for monitoring gas storage operations, and advanced precautionary measures are available to ensure system integrity. Monitoring instruments include: 
1. Observation wells for

a) obtaining pressures or fluid levels

b) detecting the presence of gas

c) scanning of the overlying layers for possible gas entry

2. Neutron logs to detect gas in porous beds behind the pipe.

3. Temperature logs to detect abnormal gradients caused by gas expansion during flow.

4. Spinner surveys to detect gas movement in casing.

5. Gas saturation logs to determine the percentage saturation at various depths.

Precautionary measures include:

1. Pump tests to evaluate caprock.

2. Threshold displacement pressure measurements on caprocks.

3. Logs of bonding between well casing and wellbore cement.

4. Downhole casing inspection logs to determine condition of casing.

5. Gas analyses from shallow water zones to identify native gases, if present.

6. Casing inspection surveys prior to running casing.

7. Cathodic protection of well pipe.

8. Water analyses.

Pressure observations on shut-in or closed off wells can be helpful in detecting caprock leakage. An observed decline in reservoir pressure to less than discovery pressure may indicate a leaking caprock (see Figure 12). This behavior occurs when the leak rate for the gas exceeds the rate at which water will return to the reservoir. A casing leak may be found by observing that the shut-in pressure in a given well is below that of adjacent wells. Annual surveys of individual shut-in well pressures over a period of a week are recommended. These surveys give precedents for pressure differences between wells. Inspection of such pressures after each survey will identify a well with a casing leak. When such occurs, simulation of well and reservoir behavior can ascertain the rate of leakage which developed and permit estimation of the gas loss over a period of time. 


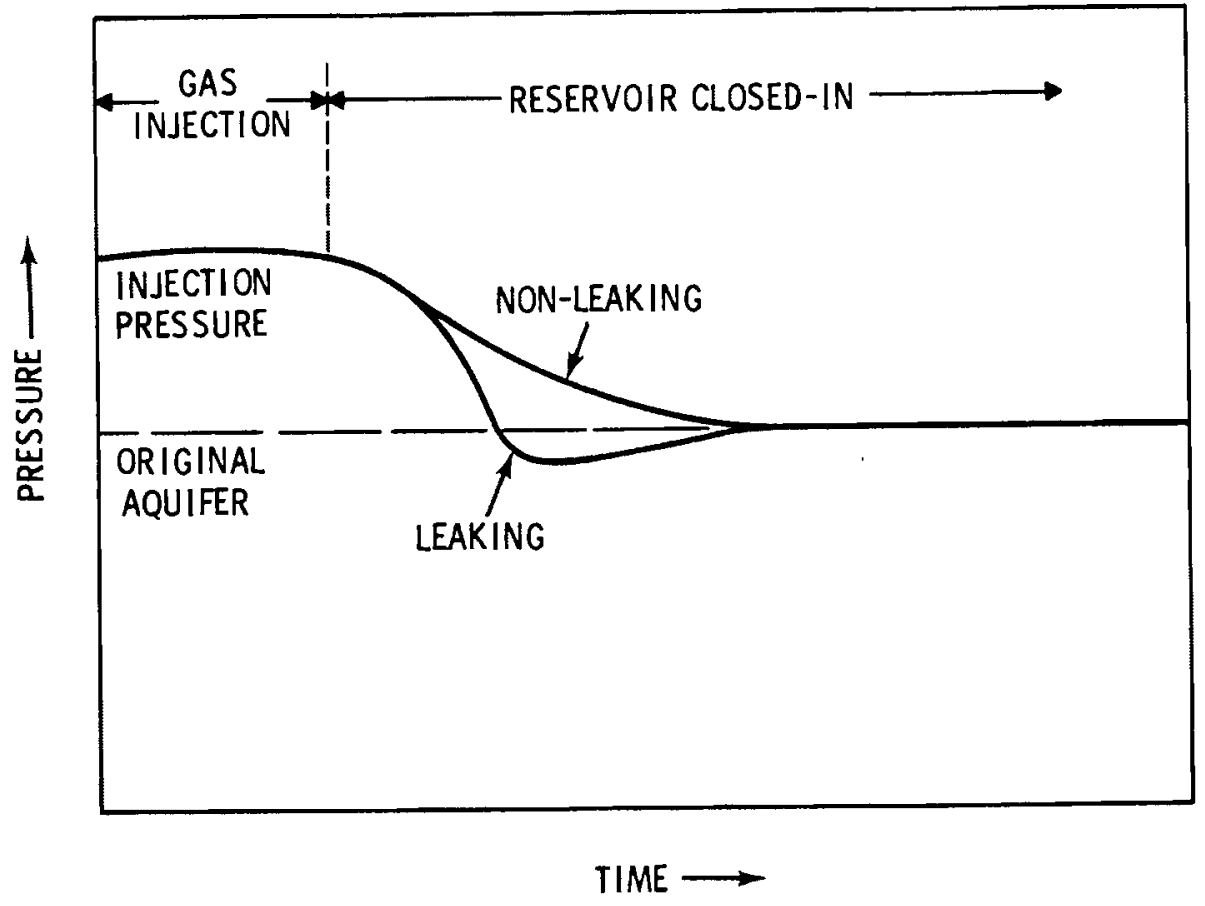

FIGURE 12. Reservoir Pressure Behavior for Leaking and Nonleaking Aquifers (Katz and Lady 1976)

\subsubsection{Natural Gas Storage Experience}

Some natural gas storage and field evaluation examples are given in which valuable experience may be found for compressed air storage development.

Herscher Galesville Aquifer. An example of a porous medium reservoir is the Herscher Galesville aquifer south of Kankakee, Illinois, shown in Figure 13 (Katz and Lady 1976). In April of 1953, it was the first sizable aquifer used in gas storage. Here a structure was found with the Galesville sand as a blanket extending for several miles in all directions. It contained only water at discovery but the water would move away when gas pressure was applied during drilling and gas injection. A large gas bubble was developed which displaced as much as 14 million $\mathrm{m}^{3}$ (494 million cubic $\mathrm{ft}$ ) of water over a period of 5 to 6 years. Unfortunately, the caprock was not completely sound; upward leakage occurred, and gas was recycled (collected and reinjected) continuously at 0.23 to 0.71 million $\mathrm{m}^{3}$ ( 8 to 25 MMcf) per day. 


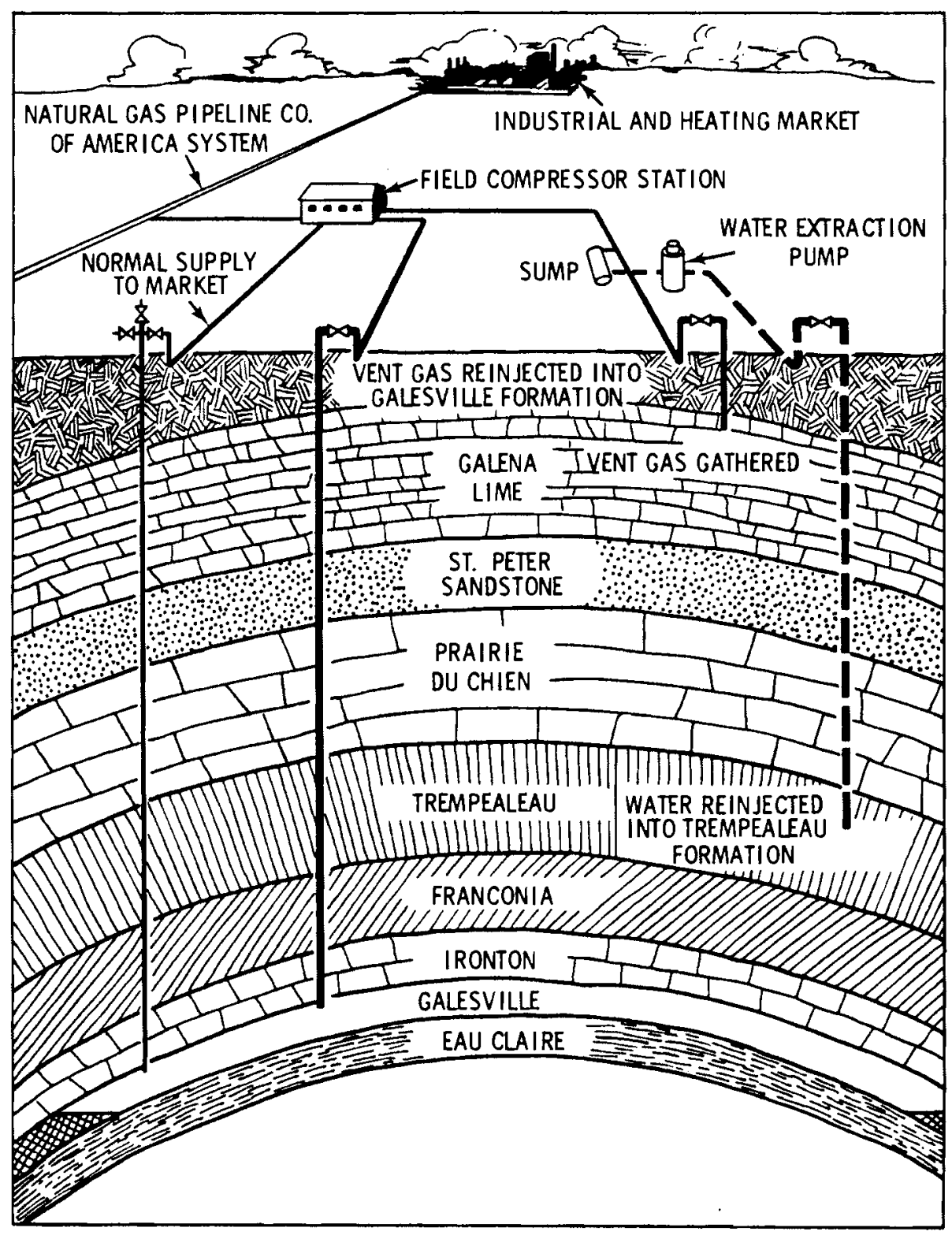

FIGURE 13. Artist's Conception of Vent Gas Cycling System at Herscher (Katz and Lady 1976) 
This reservoir has a porosity of about $19 \%$. Its permeability based upon core measurements is about 460 millidarcies, but its permeability in situ from well performance is near $3000 \mathrm{md}$. This nearly seven fold increase over core permeability is believed due mostly to fractures in the Galesville sand.

In spite of the recycling problem, the reservoir has given good service over a twenty year period. Its reservoir pressure is at some $4900 \mathrm{kPa}$ (710 to $715 \mathrm{psia}$ ) during the summer injection period and water removal by pumps helps increase the amount of gas injected. The reservoir has delivered $21.5 \mathrm{million} \mathrm{m}^{3}$ ( $760 \mathrm{MMcf}$ ) of natural gas per day. Some 340 to 400 million $\mathrm{m}^{3}$ ( 12 to 14 billion cubic $\mathrm{ft}$ ) net are removed per season, with intermittent injection during warm days in the winter.

The Herscher example proved that gas can replace water in an aquifer and create a retrievable storage bubble. Early experiences at Herscher also resulted in the development of such concepts as observation wells and threshold pressure.

Eroded Caprock Example. Exploratory and development drilling revealed an apparently suitable caprock over a proposed storage reservoir ranging in thickness from 20 to $30 \mathrm{~m}(65.6$ to $98.4 \mathrm{ft}$ ) (Rudd 1979). The caprock was arenaceous and silty shale, overlain by a sequence of interbedded shales, silts, and sandstones, apparently of deltaic origin. When the storage field was at a relatively advanced stage of development, a well drilled near the crest of the structure revealed that the caprock unit was completely absent, and the interval was filled with a thick section of shaley sandstone, including near its base some very coarse sands and pebble conglomerates. Further investigation showed that the crest of the structure was crossed by a filled stream channel, apparently of the same age as the deltaic deposits overlying the caprock. The stream had eroded through the caprock and, in places, had eroded several meters into the proposed reservoir. 
The project was abandoned at a very substantial loss, particularly since construction of surface installations was well underway by the time the absence of caprock was discovered. What is particularly notable about this example is that it was only through good fortune that the eroded stream channel was discovered. Its width was substantially less than the distance between well locations, and, had its configuration been slightly different, it might have remained undetected until gas injection was commenced. On the other hand, it is apparent that a well designed pump test program undertaken at an earlier stage of field development would have revealed a gross caprock defect and prevented much of the financial loss (Rudd 1979).

Facies Change Example. One of two domal structures, identified along the crest of an elongated anticlinal feature, was successfully developed for storage after extensive caprock evaluation by both core analysis and pump testing (Rudd 1979). Subsequently, it was decided to increase the capacity of the field by developing the second dome and increasing the thickness of the gas column so that it passed below the saddle between the two domes, making one continuous reservoir. Because of successful experience in utilization of the first dome, only minimal efforts at caprock evaluation were made in the later stage of development. This was apparently a poor practice since evidence of gas escape was noted shortly after the capacity of the field had been increased. Gas was subsequently removed from the reservoir, lowering its pressure and returning the storage capacity to approximately that of its first stage of development.

The mechanism of gas loss has not been conclusively established. However, analysis of cores obtained from the second dome (after the gas loss had been recognized) shows threshold pressures very much lower than those obtained from caprock cores overlying the first dome, and detailed macroscopic and microscopic examination reveals a marked change in caprock lithology. Relatively pure shales with thin siltstone stringers or interbeds predominated over the first dome, while over the second dome, 
not only had the thickness and frequency of siltstone interbeds increased, but the shales themselves were highly arenaceous.

An alternative explanation is that the threshold pressure at some point in the caprock, perhaps at a joint or fracture or perhaps at a particularly sandy zone, was adequate to retain gas at the lower pressure of the initial stage of development, but failed under the higher pressure of subsequent development. It is probable that more extensive caprock evaluation measures such as coring in the development of the second dome would have identified the deterioration of caprock characteristics due to facies change, the phenomenon shown in Figure 9 (Rudd 1979).

\subsubsection{Applications to Aquifer CAES}

There are obvious similarities in a natural gas storage system to proposed CAES projects. It is important that the differences are recognized and addressed and that direct applications of natural gas storage methods are not implied. The main differences between natural gas and compressed air storage systems relate to the fluid chemistry, the cycling schedule for injection and withdrawal of the fluid, and the physical environment. Air has at least twice the viscosity of natural gas; and air storage at elevated temperature may be required. Air-gas differences create concern for monitoring needs and the chemical environment in the reservoir.

Geological and physical data must be collected for CAES, just as for natural gas storage projects, in the following areas (Katz and Lady 1976):

1. Measure the available closure from a structure contour map of the top of the storage horizon. (Exploratory drilling and high resolution seismic reflection surveying are used.)

2. Check the porous medium for sufficient porosity and permeability.

3. Determine the initial aquifer pressure from its vertical distance below the water table. 
4. Determine the range of delta pressures from caprock threshold pressure measurements and permeability data.

5. Calculate the reservoir volumetric gas contents for various gas/water contact levels using core porosity, capillary pressure data, structure contour map, and delta pressures.

6. Assess the development rate for the gas bubble using unsteady-state water movement calculations.

7. Calculate the well flow rates for stated reservoir and well pressures using well spacing and storage zone permeability information.

8. Prepare a development schedule, final development state and cost estimate based upon number of wells, field lines, and compressors. Site surveys for CAES have essentially been started by the natural gas industry. Their exploration records may supplement geologic and water well information sources (Lang 1975), e.g., aquifer availability and storage characteristics. Air storage rights are not clearly defined in all parts of the United States. Compressed air injection for enhanced oil recovery has been used on numerous projects in Illinois (Lang 1975). Prior practices and regulations for fugacious fluids and hydrocarbons can expedite and facilitate acquisition and definition of storage rights.

Adverse environmental impacts due to natural gas explosion and leakage have been minimized by thorough testing programs, numerous observation wells, and specialized well design (Lang 1975). General opinion is that higher losses may be tolerated for air, and therefore some reservoirs found unacceptable for natural gas storage may be acceptable for air. The economic loss associated with compressed fluid leakage, at any significant rate, is more severe for natural gas than for compressed air. Gas migration is monitored to reduce the risks of surface combustion and damage to vegetation caused by gas interference with the capillary behavior of the soil-water system. This latter concern may also apply to compressed air leakage. 
Hazards may arise if air leaks from the storage reservoir. The air could mix with natural gas as it percolates upward, creating an explosive mixture. Chenical or biological contamination introduced during drilling operations could be carried by air to a shallower aquifer containing potable water. Test wells above a proposed air storage zone are needed to detect existing natural gas and to sample original water for quality.

\subsubsection{Thermal Energy Storage}

Past and present projects in thermal energy storage include experience in aquifers. The first three sections explain two field experiments done in the United States and some petroleum experience with water injection. Field testing plans at PNL and the application of thermal energy storage technology to aquifer CAES are addressed in the last two sections.

\subsubsection{Texas A\&M University}

Project objectives at Texas A\&M University were to design, develop and demonstrate a working prototype system in which water is pumped from an aquifer at $27.1^{\circ} \mathrm{C}\left(70^{\circ} \mathrm{F}\right)$ in winter, chilled to below $10^{\circ} \mathrm{C}\left(50^{\circ} \mathrm{F}\right)$ and stored for several months in a ground-water aquifer. The water is pumped back to the surface in summer and used to simulate air-conditioning (Reddell and Davison 1978; Reddell et al 1978). Observation wells measure water pressures and temperatures at various distances from the pumping and injection wells. Two production/injection wells were completed in the shallowest ground-water aquifer in the area, the floodplain alluvium which exists extensively along the Brazos River. Specific site and design characteristics are shown in Table 2.

A major concern with this project had been the possibility of aquifer plugging because the water was exposed to the atmosphere and aeration during the chilling process. However, prior to injection, the water went through a sand filter and all traces of iron oxides, other chemical precipitates and foreign material were removed. No evidence of aquifer plugging has occurred up to the present time. At last report the 
TABLE 2. CHARACTERISTICS OF PROTOTYPE SYSTEM AT

TEXAS A\&M UNIVERSITY

Depth of alluvium

Test we11 stratigraphy

Ground water temperature

Water table depth

Well yields

Ground water solute ions

Cooling pond area

Chilling rate

Water production rate

Cooling/injection period

Storage period (inactive)

Utilization period

Number of observation wells
$15.2 \mathrm{~m}(50 \mathrm{ft})$ to $18.3 \mathrm{~m}$ (60 ft) (average)

thick clay $0-11.6 \mathrm{~m}(38 \mathrm{ft})$

fine sand $11.6 \mathrm{~m}(38 \mathrm{ft})$ to $12.8 \mathrm{~m}(42 \mathrm{ft})$

gravel $12.8 \mathrm{~m}(42 \mathrm{ft})$ to $16.8 \mathrm{~m}(55 \mathrm{ft})$

tight blue shale $16.8 \mathrm{~m}(55 \mathrm{ft})$ and below

$18.3^{\circ} \mathrm{C}\left(65^{\circ} \mathrm{F}\right)$ to $21.1^{\circ} \mathrm{C}\left(70^{\circ} \mathrm{F}\right)$

$3.05 \mathrm{~m}(10 \mathrm{ft})$ to $9.1 \mathrm{~m}(30 \mathrm{ft})$

$15.81 / \mathrm{s}(250 \mathrm{gpm})$ to $63.11 / \mathrm{s}(1,000 \mathrm{gpm})$

$\mathrm{Na}^{++}, \mathrm{Ca}^{++}, \mathrm{Fe}^{++}, \mathrm{Cl}^{-}$

$465 \mathrm{~m}^{2}\left(5,000 \mathrm{ft}^{2}\right)$

$6.31 / \mathrm{s}(100 \mathrm{gpm})$ for 5 mos.

up to $12.6 \mathrm{l} / \mathrm{s}(200 \mathrm{gpm})$

October through March

April through May

June through September

aquifer was still taking water at the rate of 2.07 to $2.48 \mathrm{1} / \mathrm{s} \mathrm{m}$ (10 to $12 \mathrm{gpm} / \mathrm{ft}$ ), which was the original capacity.

\subsubsection{Auburn University}

The Water Resources Research Institute of Auburn University is performing an aquifer injection and recovery experiment involving heated water (Warman and Molz 1977; Molz and Paar 1978; Molz and Warman 1978; and Molz et al 1978). Water temperatures are recorded in observation wells to test the predictive accuracy of numerical models which describe water and heat transport below the water table. 
Physical characteristics of the Mobile aquifer (and aquitard) used in the first experiment are shown in Table 3. Pumping tests disclosed finite hydraulic behavior, and it is suggested that the aquifer is coincident with a buried river channel.

The first six-month experiment, schematically shown in Figure 14, involved the injection and recovery of about $54,900 \mathrm{~m}^{3}$ (14.5 million gal) of water (Molz and Paar 1978; Allen 1978(a) $)$. The injection water, obtained from the formation water of an unconfined aquifer above the storage aquifer was heated to a temperature of about $55^{\circ} \mathrm{C}\left(131^{\circ} \mathrm{F}\right)$, and injected into a $9.1 \mathrm{~m}(30 \mathrm{ft})$ section of the confined storage aquifer. The recovery period was terminated when the water being withdrawn from the storage aquifer fell from an initial temperature of $55^{\circ} \mathrm{C}\left(131^{\circ} \mathrm{F}\right)$ to $33^{\circ} \mathrm{C}$ $\left(91.4^{\circ} \mathrm{F}\right)$ which was $13^{\circ} \mathrm{C}\left(23.4^{\circ} \mathrm{F}\right)$ above the ambient water temperature in the confined aquifer. The average rate of decline in water temperature was $0.5^{\circ} \mathrm{C} /$ day $\left(0.9^{\circ} \mathrm{F} /\right.$ day $)$. About 65 percent of the injected energy was

\section{TABLE 3. PHYSICAL CHARACTERISTICS OF THE AUBURN UNIVERSITY AQUIFER}

Hydraulic gradient

Porosity

Hydraulic conductivity

Pore velocity

Formation temperatures, initial

Thermal conductivity (matrix + water)

Thermal conductivity (aquitard)
$2.96 \times 10^{-4}$ (toward Northwest)

0.25

$44 \mathrm{~m} /$ day $(144.5 \mathrm{ft} /$ day $)$

$5.18 \mathrm{~cm} /$ day $(0.17 \mathrm{ft} /$ day $)$

$19.8^{\circ} \mathrm{C}\left(67.64^{\circ} \mathrm{F}\right)$ (Top)

$20.05^{\circ} \mathrm{C}\left(68.09^{\circ} \mathrm{F}\right)$ (Middle)

$20.3^{\circ} \mathrm{C}\left(68.54^{\circ} \mathrm{F}\right)$ (Bottom)

$0.00055 \mathrm{kcal} / \mathrm{s} \mathrm{m}{ }^{\circ} \mathrm{C}\left(1.33 \mathrm{Btu} / \mathrm{hr} \mathrm{ft}{ }^{\circ} \mathrm{F}\right)$

$0.00061 \mathrm{kcal} / \mathrm{s} \mathrm{m}^{\circ} \mathrm{C}\left(1.48 \mathrm{Btu} / \mathrm{hr} \mathrm{ft}^{\circ} \mathrm{F}\right)$

(a) R.D. Allen, Pacific Northwest Laboratory Report on "Low Temperature Thermal Energy Storage Technical Review Committee Meeting," Denver, c0 November 6, 1978. 


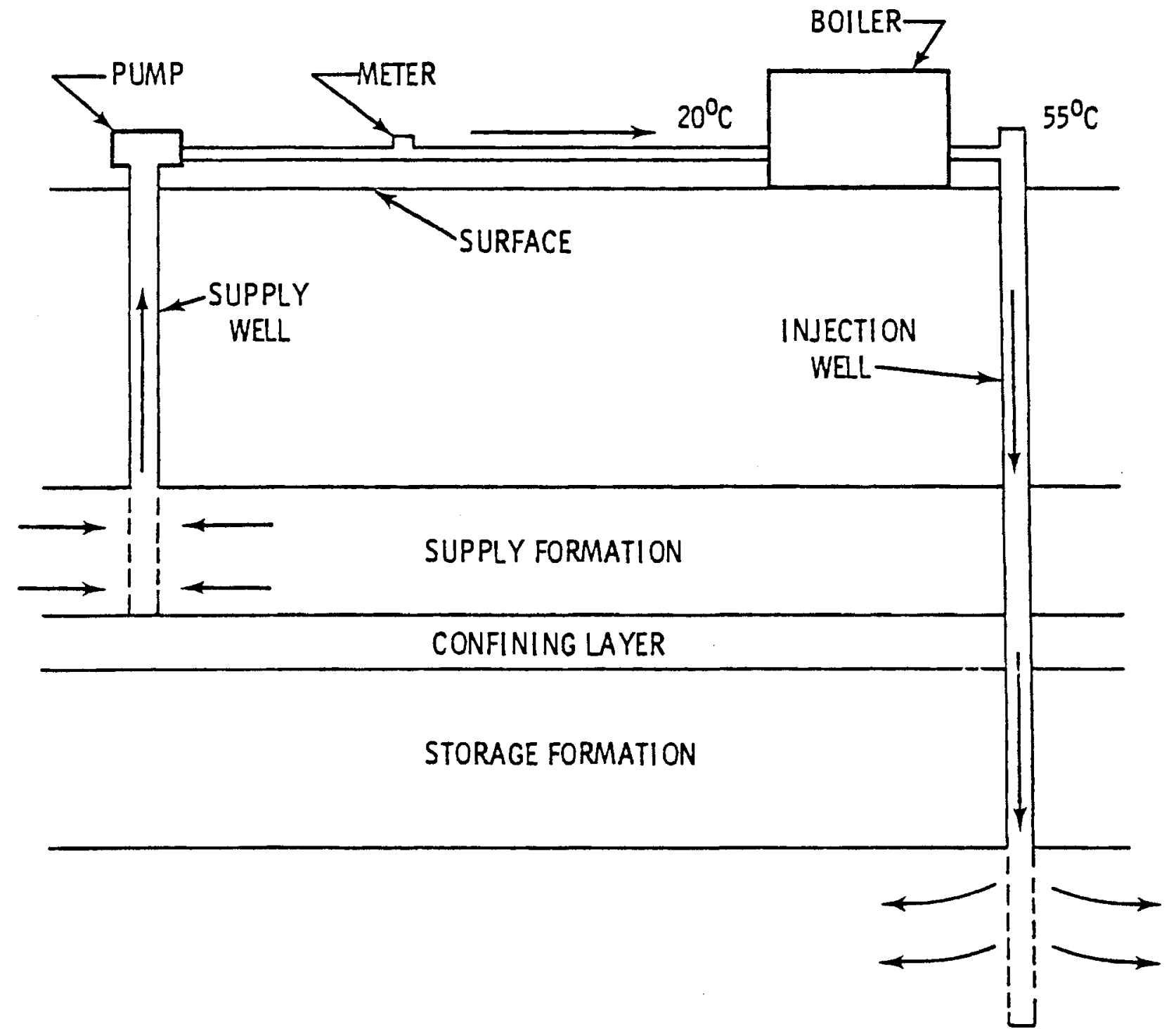

FIGURE 14. Schematic of Second Aquifer Experiment at Auburn University

recovered. The clogging problems that plagued a preliminary experiment, in which surface water was injected, were significantly reduced during the first six-month experiment, apparently due to the relatively low level of suspended solids in the injection water and periodic backwashing of the injection well. No vertical mixing or buoyancy displacement of water was observed. 
The second six-month experiment (ATES Newsletter, May 1979) was performed in the same manner as the first. About $58,000 \mathrm{~m}^{3}(15.3$ million gal) of water was heated to an average temperature of $55.4^{\circ} \mathrm{C}$ $\left(131.7^{\circ} \mathrm{F}\right)$ and injected into the confined aquifer. When the water temperature reached $32.8^{\circ} \mathrm{C}\left(91^{\circ} \mathrm{F}\right)$ during the recovery period, $73.8 \%$ of the injected energy had been recovered. The experiment continued until the outflow temperature reached $27.5^{\circ} \mathrm{C}\left(81.5^{\circ} \mathrm{F}\right)$. It still remains to be seen what effects higher temperatures will have on the hydraulic conductivity of typical formation soils. Subsequent systems may inject water at temperatures up to $200^{\circ} \mathrm{C}\left(392^{\circ} \mathrm{F}\right)$.

The following observations and conclusions (Molz and Warman 1978) were reached after the first six-month experiment:

1. The natural velocity of ground water should be very low. If not, the gradient must be lowered by artificial means.

2. Long operation of a heat storage well will require cycling of water with extremely low suspended solids. (A hundred million gallons $\left(3.786 \times 10^{8} 1\right)$ of water with suspended solids of 1 part per million contains $836 \mathrm{lbs}(379 \mathrm{~kg})$ of suspended material.) It is likely that clogging will be one of the most serious problems concerning the intermediate to long-term operation of heat storage wells.

3. If a storage aquifer contains clay, even in small amounts, clay swelling may seriously impair injection. The $\mathrm{pH}$ and iron content of the water must be compatible with the particular clay mineral. Even exposure to distilled water can cause some clays to swell. Also, the injected water must neither precipitate any chemical compounds within the aquifer pores (or onto the aquifer matrix) nor dissolve the matrix material.

4. Hydraulic conditions must not be imposed capable of causing failure of the confining stratum. High temperature water may weaken aquitard materials or increase their permeabilities. The effect of temperatures in the 60 to $204^{\circ} \mathrm{C}\left(140\right.$ to $\left.400^{\circ} \mathrm{F}\right)$ range on mechanical and hydraulic properties of aquitard materials should be studied. 
5. The thermal recovery factor of 0.68 was considered encouraging in view of the small volume injected. Simulation studies (Papadopulos and Larson 1978) predict high recovery factors for storage wells involving hundreds of millions of gallons of heated water.

6. Anomalously low temperatures have been measured in observation wells. The effect appears to be due to mixing of hotter water in the lower portion of the well (within the storage formation) with cooler water in the casing above the formation.

7. One procedure for minimizing chemical or mechanical clogging of an injection well is to use formation water. Ground water tends to be low in suspended solids, and the main difference between the injected water and the native water will be one of temperature.

8. In order to further develop the heat storage well concept, additional experimental studies are needed involving larger volumes of water and higher injection temperatures. The geochemistry - colloid chemistry problem must be studied carefully, and the effect of high temperatures on the mechanical and hydraulic properties of clay confining layers must be determined.

9. The Auburn experiment will provide field data which can be compared with computed data from the LBL/CCC numerical model ${ }^{(a)}$. This experiment and others may indicate that one or more perturbations would improve the model.

\subsubsection{Petroleum Experience in Water Injection}

Water injection related to petroleum recovery has developed data germane to thermal energy storage in aquifers (Subcasky 1978). The quality of the water is important because it involves physical and chemical factors which could change the permeability of the receiving formation or affect the equipment used to process and inject the water. Factors of concern discussed in this section include: water chemistry,

\footnotetext{
(a) Lawrence Berkeley Laboratory has performed detailed calculations to model Auburn University experiments (ATES Newsletter, May 1979).
} 
water/rock interactions, particulate plugging, scaling, corrosion, bacteria, temperature and water treatment chemicals.

Changes in water temperature or pressure can cause precipitation of solid phases. For example, a pressure decrease may cause release of carbon dioxide which, in turn increases alkalinity and decreases solubility of calcium carbonate. The solubility of calcium carbonate also decreases with increasing temperature. In contrast, the solubility of gypsum, $\mathrm{CaSO}_{4} \cdot 2 \mathrm{H}_{2} \mathrm{O}$, increases with increasing temperature. A precipitate may deposit on conduit walls, increasing the hydraulic pressure gradient, or it may be suspended in the liquid, providing a potential plugging agent within the receiving formation.

Mixing of waters from two sources can cause precipitation due to comingling of diverse ions, e.g., $\mathrm{Ba}^{++}$and $\mathrm{SO}_{\overline{4}}$ to yield $\mathrm{BaSO}_{4}$, or mixing of highly alkaline water with another containing high calcium or magnesium can cause precipitation of calcium carbonate and magnesium hydroxide.

Water/rock interactions may have significant effects. Minerals with layered structures like clays and micas can exchange cations with cations in solution and undergo changes in layer spacings, e.g., replacement of potassium in mica by sodium or calcium can increase the spacing by $50 \%$.

Altering the electric field around a charged clay species by changing the electrolyte composition can cause dispersion or coagulation of particles. Dispersed particles can migrate and plug small pores.

Injected water may partially dissolve the host rock. Calcium carbonate can be dissolved by undersaturated or acid water. Siliceous minerals can be dissolved by alkaline and/or high temperature water. Reductions in $\mathrm{pH}$ or temperature can cause redeposition of silica and possible reduction of permeability.

Particulate plugging can also arise from material in the injection water before its introduction or from material formed or produced within 
the receiving formation. Possible sources of particulates in injection water include the following: silts, formation fines, corrosion products, scale deposits, bacteria and chemical precipitates. Water/rock or water/water interactions within the formation can form or dislodge particles which subsequently reduce formation permeability. Particle size, shape, number; fluid velocity; and pore size, shape and number influence the effect. A filter cake may develop on the injection well face or plugs and bridges may develop within the formation.

Scaling is the formation of an insoluble deposit from a physical or chemical change in water or from mixing of two waters not in chemical equilibrium. Scaling may occur on the walls of processing or injecting equipment or within the formation itself. Scale may also slough, putting particles into suspension, or it may redissolve.

Corrosion is chemical attack upon metallic components by active agents within the water. Corrosion rate depends upon $\mathrm{pH}$ level, temperature, solute species and concentration, fluid velocity, and presence of corrosive gases, e.g., oxygen, carbon dioxide and hydrogen sulfide. Corrosion causes damage to processing and injection equipment which may reduce efficiency or cause failure. Corrosion products, usually iron oxides and sulfides, can also plug the receiving formation.

Bacteria can form slimes which may plug the formation or filters. Colonies on pipe walls can form oxygen concentration cells which accelerate corrosion and pitting. Sulfate reducing bacteria can release hydrogen sulfide--highly corrosive and toxic. Both oxygen and hydrogen sulfide may attack the injection, production, and heat exchange sys tems.

The effective permeability of the formation is also related to the temperature of the injected fluid. A temperature rise causes decreases in fluid density and viscosity. The net effect may change the required pumping pressure. Rock solubility and reactivity are also temperature dependent. 
Water treatment chemicals may be added to inhibit deleterious effects. These may include scale inhibitors, corrosion inhibitors, biocides, demulsifiers, solvents, acids, etc. However, these chemicals should be chosen to avoid mutual reactions or reactions with water solutes/suspensions to form plugging precipitates. The use of native aquifer water as the working fluid may inhibit or eliminate many problems because the only fluid property difference would be temperature.

\subsubsection{Seasonal Thermal Energy Storage (STES)}

The STES program at Pacific Northwest Laboratory involves the drilling of test wells to identify aquifer characteristics by coring, pump testing, and geophysical logging of the formation. Groundwater samples will be analyzed for geochemical properties. The thermal plume developed by warm water injection will be monitored with thermistors. Thermal stresses developed in well completion cements due to cycling of injection and withdrawal will be monitored through in-hole instrumentation and geophysical logging. The physical and chemical response of the aquifer system to these altered waters, and the temporal and spatial variability of the plume are the primary unknowns in the STES program.

It is predicted that thermal alteration of the ground water could alter the aquifer flow characteristics in at least two ways: 1) reduced viscosity of the water could effectively increase the permeability; and 2) the increased temperature could affect the chemical reactivity of the water and sediment causing plugging. Continuous measurement of flow rates and pressures together with water-level measurements in the observation wells will allow monitoring of these phenomena.

The effect of regional ground water flow on the injected thermal "bubble" is unknown. Comparison of thermal distribution data with tracer arrival data will allow calculation and determination of these ground-water flow effects.

\subsubsection{Applications to Aquifer CAES}

The Seasonal Thermal Energy Storage (STES) Program is based upon injection of thermally conditioned water into aquifers, periodic storage, 
then water withdrawal for utilization. Potential applications of this technology to the aquifer CAES program lie in two general areas: 1) aquifer and caprock characterization, and 2) aquifer utilization. Field determinations of structural-stratigraphic traps and aquifer hydrology will involve similar methods for both STES and CAES. Although it is unlikely that the same aquifer would be used for both storage schemes, the same methods of field and laboratory evaluation will be used to obtain and analyze core samples. The reservoir petrologic properties of interest to both storage technologies include: permeability, porosity, thermal conductivity, thermal expansivity, thermal fatigue, friability, hydrolytic stability and silica solubility. The permeability, fatigue strength and thermal conductivity of the caprock are vital to both technologies. Similarity in aquifer utilization occurs because each energy storage mode involves the displacement and compression of water within an aquifer. Also, thermal gradients are imposed upon the water within the aquifer. However, the depths relevant to STES may be substantially less than those required for CAES. Some aspects of aquifer modeling may be applicable to both.

Preliminary aquifer considerations, identified for thermal energy storage by Allen (1979), are directly or partially applicable to compressed air energy storage. These are repeated or modified as follows:

- Natural horizontal movement of ground water in the aquifer must be relatively small to effect compressed air containment and recovery.

- The volume and permeability available within the aquifer must be sufficient to make possible acceptance and delivery of the designated fluid (compressed air) quantity at the required rates.

- The aquifer and confining rock formations must be capable of storing compressed air at the required maximum containment pressure without excessive leakage and without hydraulic or pneumatic fracturing.

- The aquifer system and overlying strata must not undergo significant vertical deformation or displacement during inflow or outflow. 
- The aquifer/aquitard system must not be susceptible to significant fatigue effects due to cycling of compressed air and aquifer water migration.

- A confined storage aquifer should be hydraulically isolated from existing or potential potable water sources.

- The aquifer probably should not contain significant quantities of calcareous minerals, mica, clay minerals, sulfates, evaporites or other minerals susceptible to hydration or dissolution.

- Not more than a small percentage of the stored fluid volume is to be lost through aquitard caprock and foundation beds during an input/storage/output cycle.

- The system sha11 not damage the environment with respect to thermal pollution, migration of toxic materials, land subsidence or uplift, or seismicity.

- The available aquifer storage volume should remain sensibly constant with respect to time to assure constancy of performance.

\subsubsection{Geothermal Energy}

Geothermal investigation normally involve more severe environments of temperature, pressure and chemical reactivity than those projected for compressed air energy storage. Nevertheless, particular aspects of technical commonality occur in three areas: 1) site evaluation, 2) reservoir engineering, and 3) well field monitoring. Representative information has been drawn from the geothermal 1iterature which may apply to CAES-in-aquifer technology.

\subsubsection{Site Evaluation}

Geophysical methods and exploratory drilling are used to delineate promising geothermal sites. Electrical resistivity measurements have been made both regionally at the surface and within exploratory holes to locate geothermal reservoirs. This method is also used to log geothermal 
discovery wells or regional exploration wells (Jiracek and Gerety 1978). The principle is that electrical current introduced directly into the conductive geothermal reservoir will experience more pronounced channeling than current from a surface source.

Applegate and Donaldson (1979) described the application of seismic reflection techniques in defining structural controls within geothermal fields. Improved high-resolution methods have yielded more consistent data enabling subsurface mapping of complex structures associated with geothermal systems. This modern instrumentation includes geophones with a high natural frequency, amplifiers with a very wide dynamic range, and filters with the flexibility to emphasize higher frequency data.

\subsubsection{Reservoir Engineering}

Reservoir engineering and well development deal with the pragmatic aspects of geothermal field exploitation. According to Nicholson (1978) matrix type hot water reservoirs are highly susceptible to near wellbore permeability reduction due to drilling fluid filtrate and particle invasion. He recommends the following steps to reduce formation damage: 1) use drilling fluid materials which do not have adverse high temperature properties; 2) formulate a liquid phase compatible with formation solids and fluids; 3 ) minimize the wellbore-to-formation pressure differential; and 4) flow sufficient volumes from the well as soon as possible after drilling to back-flush invader particles and filtrate.

Rand (1979) recommends aqueous foam for drilling geothermal wells because it will not damage the producing formation and will eliminate the erosion problems of air drilling. Successful use of aqueous foam will require a high-foaming surfactant which will be chemically and physically stable under the geothermal environment. The most promising surfactant types tested were the alkyl and alkyl aryl surfonates and the ethoxylated nonionics.

Well completion involves installation of the casing and cementing of the annular space between the steel casing and the formation wall. 
Godare (1978) and Karlsson (1978) addressed problems in casing design caused by pressure and temperature. Of the various load combinations acting on the casing string, the most critical appear to be internal pressure and thermal expansion. Eilers (1978) and Nelson et al (1979) state that cementing of geothermal wells requires special consideration for elevated temperatures, corrosive fluids, and fragile formations. silica-stabilized Portland cement showed promise in this area.

Borehole temperature surveys are essential in geothermal well development. Dennis and Murphy (1978) described a borehole temperature sonde which uses a thin-walled stainless steel thermistor probe as the sensor. Thermistors are well suited for continuous measurements above $300^{\circ} \mathrm{C}\left(572^{\circ} \mathrm{F}\right)$. Kratz et al (1979) designed and tested a geothermal sonde for measuring temperature and pressure using no downhole electronics at temperatures up to $275^{\circ} \mathrm{C}\left(527^{\circ} \mathrm{F}\right)$ and pressures of at least $69 \mathrm{MPa}$ $(10,000$ psi).

Wonn (1978) described a well logging tool, the borehole televiewer, which provides an acoustic image of the borehole surface, delineating wall discontinuities, formation dip, fracture patterns, vugs, and washouts. The sensor uses an acoustic beam directed at a piezoceramic disc. Demonstrated capabilities include mapping of fracture zones, bedding and other features. The device has been used in cased wells to map cavitation, pitting, perforation plugging or enlargement, and casing breaches.

Sanyal and Jusbasche (1979) presented a simple statistical technique for estimating average geothermal water salinity from any well section. The method is based on cross-plotting resistivity data from shallow and induction well logs. The slope is proportional to the salinity. This method contrasts with more expensive methods which require processing of digitized well logs on a computer.

Pettitt (1975) described hydrologic testing in a $1937 \mathrm{~m}(6353 \mathrm{ft})$ deep exploratory hole within Precambrian granite beneath the Jemez 
Mountains, New Mexico. Flow testing, shut-in pressure testing, and injection testing indicated relative impermeability. The hydrology tests correlated well with geophysical logs.

Haney et al (1979) reviewed Lawrence Berkeley Laboratory geotherma 1 well testing equipment. Sandia's development of high temperature electronics and the introduction of high temperature cable has increased the temperature range of some instruments utilizing downhole active electronics to $275^{\circ} \mathrm{C}\left(527^{\circ} \mathrm{F}\right)$. Previous $7 y$, for the measurement of temperature, pressure and flow above $150^{\circ} \mathrm{C}\left(302^{\circ} \mathrm{F}\right)$, reservoir engineers had to rely on less accurate non-electrical instrumentation.

Veneruso and Stoller $(1978,1979)$ identified prototypic geothermal logging tools for use up to $275^{\circ} \mathrm{C}\left(527^{\circ} \mathrm{F}\right)$. These include: temperature, pressure, flow, caliper, casing collar locator, formation resistivity, fracture mapping, casing and cement inspection, directional survey, and sonde refrigeration. These logging tools use innovative components such as high temperature electronics, high temperature-high resolution pressure transducers, elastomeric and metal tool seals, cableheads and cables. An experimental high resolution quartz pressure transducer has been tested successfully at $275^{\circ} \mathrm{C}\left(527^{\circ} \mathrm{F}\right)$ and $6.9 \mathrm{MPa}$ (1000 psi).

Denlinger et al (1979) combined gravity and geodetic data with reservoir engineering studies to place upper and lower bounds on the volume and pore fluid mass changes within the depleted portion of the steam reservoir at The Geysers, California. Gravity and temperature data were used to constrain the changes in pore fluid mass distribution due to fluid depletion. The drainage volume was accordingly bounded between 15 and $25 \mathrm{~km}^{3}$ (3.6 to $6.0 \mathrm{mi}^{3}$ ). If the liquid saturation in one section of the reservoir may be extrapolated to other sections, knowing the rate of mass depletion, a lifetime estimate can be calculated for the whole steam field.

Goranson and Schroeder (1979) have summarized site specific geothermal reservoir engineering activities at Lawrence Berkeley Laboratory. They cite the following general purposes for geothermal exploratory well testing: 
- Determine hydrological parameters.

- Identify aquifer limits (barriers).

- Identify aquifer recharge (if it exists).

- Determine well damage (if it exists).

- Determine thermal characteristics.

- Obtain representative reservoir fluid sample.

\subsubsection{Well Field Monitoring}

Many of the borehole logging and hydrological techniques briefly described in Sections 3.2.3.1 and 3.2.3.2 are also applicable to well field monitoring. Several additional methods are identified below.

The possibility and consequences of land subsidence associated with geothermal production has been a significant concern. Crow and Kasameyer (1978) describe monitoring procedures used in the Imperial Valley, California. Benchmark and seismographic networks are in place. In an earthquake triggered by geothermal withdrawal, the depth of focus would be expected to coincide with the reservoir depth, i.e., 1 to $2 \mathrm{~km}$ $(0.62$ to $1.24 \mathrm{mi})$. Fortunately, virtually all recorded events originated below $4 \mathrm{~km}$ (2.5 miles).

Pettitt (1975) described the installation of a seismic net at a geothermal site in New Mexico. The stations allowed detection of sonic events associated with downhole fracturing and monitoring of hydraulic fracture experiments to obtain advance warning of stress build-up which might cause earth tremors.

\subsubsection{Applications to Aquifer CAES}

Geophysical methods, used in geothermal exploration, with potential value for locating candidate CAES aquifer sites include electrical resistivity and seismic reflection techniques.

Reservoir engineering technology offers innovations which may improve the economics of CAES field development. These include advanced 
drilling, casing and cementing methods, hydrology tests to measure permeability, storage well logging with high temperature-high pressure devices and gravimetric surveying.

Well field monitoring methods, in use at geothermal reservoirs, may be applied to compressed air reservoir monitoring. These include seismographic networks to detect tremors or subsidence, well logging and ground-water analysis.

\subsubsection{Hydrogen Storage}

Hydrogen is also being considered for storage in porous media such as aquifers and depleted natural gas fields. The Underground Storage of Hydrogen Project (Randolph et al 1978) commenced in August of 1978. Program objectives were to:

1. Establish the engineering feasibility of using geologic or engineered underground sites for hydrogen storage.

2. Identify the research and development needs related to both cost reduction and safety problems.

3. Identify possible sites where hydrogen may be stored.

4. Develop realistic cost estimates for underground hydrogen storage facilities.

Accomplishing the program objectives involves consideration of four types of storage facilities. These include aquifers, depleted gas fields, washed salt caverns, and mined caverns. The first two, being porous media, are included in Sections 3.2.4.1 and 3.2.4.2 with discussion of their engineering feasibility. Design characteristics drawn from the aquifer and depleted gas fields studies are shown in Tables 4 and 5.

\subsubsection{Aquifer Storage}

Figure 15 illustrates the concept of aquifer storage. The geological requirement is the existence of an anticline in a water-saturated porous formation that is overlain by a highty impermeable caprock. Storage is 


\section{TABLE 4. MEDIA STORAGE FIELD (HENDERSON COUNTY, ILLINOIS)}

(RANDOLPH ET AL 1978)

Storage Type

Storage Formation

Year Activated

Average Depth of Reservoir

Capacity Volume at STP

Pressure a Capacity

Base Volume

Pressure @ Base

Deliverability at STP

Wells - Injection and Withdrawal

Wells - Observation

Installed Horsepower

Storage Area
Aquifer

Galesville

Not in service

$610 \mathrm{~m}(2,000 \mathrm{ft})$

$58.37 \times 10^{4} \mathrm{~m}^{3}\left(20.6 \times 10^{6} \mathrm{ft}^{3}\right)$

$6.38 \mathrm{MPa}(925 \mathrm{psig})$

$45.34 \times 10^{4} \mathrm{~m}^{3}\left(16 \times 10^{6} \mathrm{SCF}\right)$

$6.38 \mathrm{MPa}$ (925 psig)

$2.83 \times 10^{3} \mathrm{~m}^{3}\left(10^{5} \mathrm{ft}^{3} / \mathrm{d}\right)$

5

8

1,864 kWe $(2,500 \mathrm{Hp})$

1,017 ha $(2,510$ acres $)$

This field has not yet been placed in service, but it was selected due to the comprehensive data available in the public domain. It is designed to be one of several fields operating to meet both peaking and annual load balancing requirements of a large distribution company. As presently visualized, single-day deliverability would be about $2.2 \%$ of working gas capacity. This is a percentage somewhat higher than available from the Hanson Field (see Table 5), but still less than may be required to meet peaking demands for a small distribution company serving predominantly residential consumers. 
TABLE 5. HANSON STORAGE FIELD (HOPKINS COUNTY, KENTUCKY)

(RANDOLPH ET AL 1978)

\author{
Storage Type \\ Depleted Gas Reservoir \\ Storage Formation \\ Tar Springs \\ Year Activated \\ 1965 \\ Average Depth of Reservoir \\ $686 \mathrm{~m}(2,250 \mathrm{ft})$ \\ Capacity Volume at STP \\ $342.6 \times 10^{6} \mathrm{~m}^{3}\left(12.09 \times 10^{9} \mathrm{ft}^{3}\right)$ \\ Pressure o Capacity (psig wt-ht) \\ $6.92 \mathrm{MPa}(1,003 \mathrm{psig})$ \\ Base Volume at STP \\ $231.2 \times 10^{6} \mathrm{~m}^{3}\left(8.16 \times 10^{9} \mathrm{SCF}\right)$ \\ Pressure o base (psigwt-ht) \\ 4. $67 \mathrm{MPa}$ (677 psig) \\ Deliverability at STP \\ $2.02 \times 10^{6} \mathrm{~m}^{3} / \mathrm{d}\left(71.402 \times 10^{6} \mathrm{ft}^{3} / \mathrm{d}\right)$ \\ Wells - Injection and Withdrawal \\ 30 \\ Wells - Observation \\ 2 \\ Installed Power \\ $492 \mathrm{kWe}(660 \mathrm{Hp})$ \\ Storage Area \\ 1,224 ha $(3,021$ acres $)$ \\ This is one of several storage facilities providing annual load balancing \\ for an interstate pipeline system. Many of the customers are distribution \\ companies which have their own storage for peaking and a portion of \\ annual load balancing. In this market environment, single-day deliverability \\ of only $1.8 \%$ working gas volume is adequate.
}




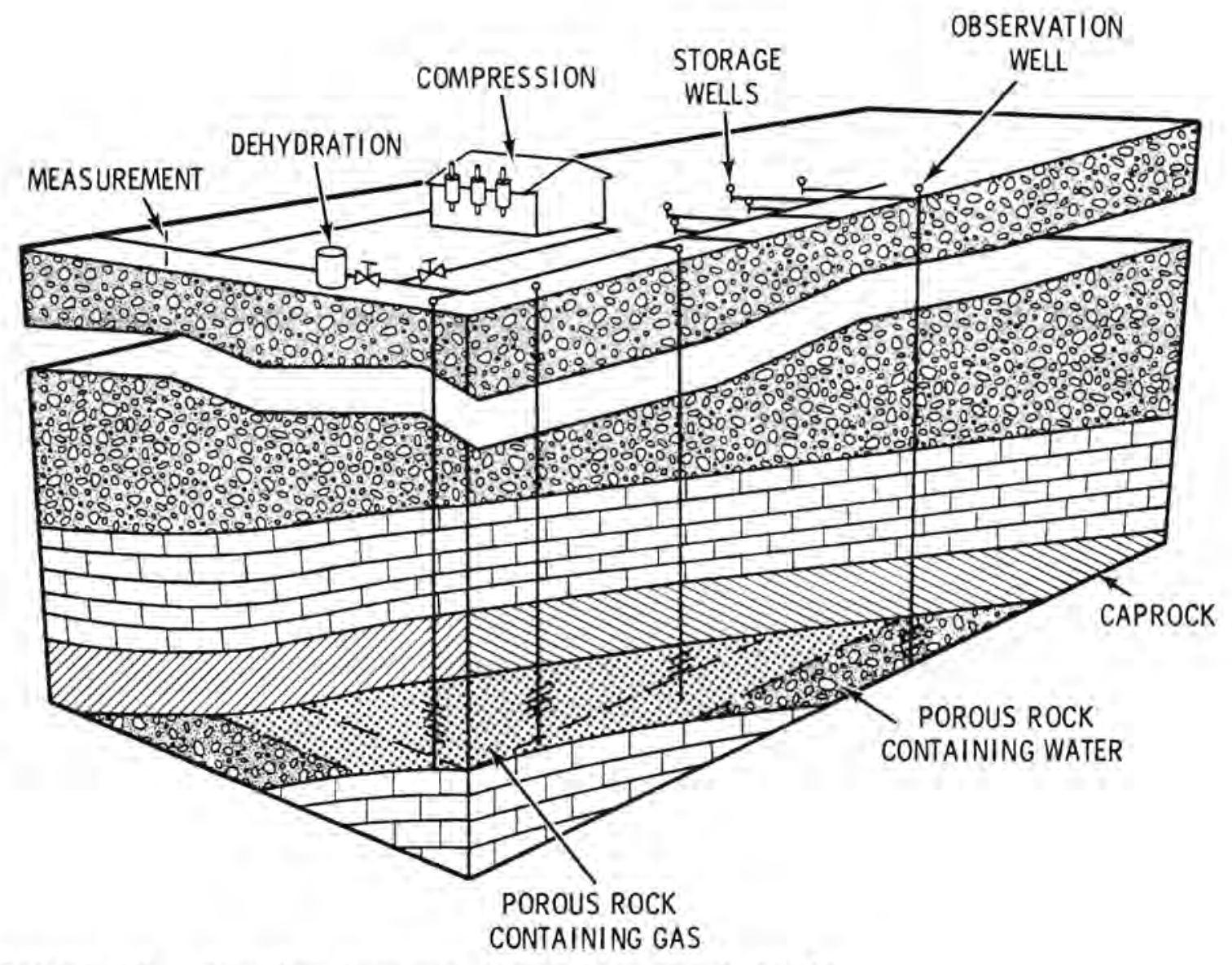

FIGURE 15. Aquifer Storage (Randolph et al 1978)

accomplished by pumping gas into the top of the anticline to displace the original water. The injection pressure, and therefore the rate, must be 1 imited so that the capillary forces that provide the caprock sea 1 are never exceeded. Withdrawal rate from storage must be low enough that the pressure sink at a withdrawal well does not result in upward coning of underlying water which could block gas production. Realistically several years may be required to reach the full storage capacity of an anticline. Also, even with multiple wells, the maximum practicable withdrawal rate is believed to be less than $1 \%$ of stored gas per day. 
In the case of hydrogen storage, "base" gas and "nonrecoverable" gas are critically important considerations. Base gas is the fraction of total injected gas that is not normally withdrawn during annual cycles of storage operation. For aquifers, this may be approximately two-thirds of the total gas inventory. The cost of hydrogen base gas will probably be several times greater than all other costs of the storage facility. Nonrecoverable gas is the portion of the gas that can never be recovered due to economic considerations of pumping costs or dilution, or because it will be bypassed by water and trapped in place. Estimating nonrecoverable gas and defining the economic implications are key elements.

\subsubsection{Depleted Gas Fields}

Depleted natural gas fields are widely used for natural gas storage. The geological environment is similar to that shown in Figure 15 for aquifer storage. The major differences are:

- A substantial amount of natural gas remains when operating costs exceed the value of production from a gas field. This remaining natural gas will mix with hydrogen during use for hydrogen storage.

- Permeability of the rock formations is generally lower than for aquifers so that pressure drop in the vicinity of each well, rather than water coning, limits withdrawal rate.

- Many depleted fields involve substantially greater depths and storage pressures than the aquifers that have been used for storage to date.

\subsubsection{Applications to Aquifer CAES}

Participants in the hydrogen program are optimistic that underground storage of hydrogen will be found to be practical. Although there is no actual field experience with hydrogen storage in porous media, the planning process may offer technology to CAES field study planning. This technology has its basis primarily in natural gas experience with an emphasis on estimation of nonrecoverable gas and other economic 
evaluations. The economic consideration for air is less serious because the economic loss for the nonrecoverable air is only related to the compression/injection process. Geologic containment of hydrogen gas may be considerably more difficult than containment of either natural gas or air because hydrogen's molecular diameter and weight are about an order of magnitude less. Hydrogen embrittlement of ferrous hardware may also be a significant problem. In addition, the combustion hazard of both contained and leaked hydrogen must be overcome, including a substantial safety margin, to meet environmental requirements. 


\subsection{STATE-OF-THE-ART IN POROUS MEDIA CAES RESEARCH AT PNL}

Pacific Northwest Laboratory is conducting and sponsoring research and development in compressed air energy storage within porous geologic formations. The objective is to develop reservoir design and stability criteria to enable storage and utilization of compressed air over long time periods. Preliminary design criteria were assembled by extensive review and extraction of data generated by the petroleum industry. Numerical modeling studies are structured to examine reservoir pressure, temperature and humidity profiles as functions of time as well as examine the structural stability of the storage matrix and caprock. Laboratory experiments involve the imposition of simulated CAES conditions upon reservoir and caprock test specimens. Field studies will embrace air injection into a shallow substructural aquifer trap; cycling of air at ambient and elevated temperatures; monitoring of reservoir and caprock temperatures, hydrostatic pressures and water saturations; and laboratory analysis of geochemical and rock mechanical effects. Final design and stability criteria will be drawn from the integrated body of technical results.

\subsection{PREL IMINARY DESIGN CRITERIA}

An ideal storage matrix within an anticlinal or domal geologic structure is illustrated in Figure 16. A practical storage field would support multiple wells (probably 100 or more) and would not have the severe vertical exaggeration depicted. Some recommended characteristics of such a system are as follows (Stottlemyre et al 1979):

- The porosity and permeability of the reservoir must be sufficient to receive, store and deliver an air mass of acceptable volume. This requirement depends on characteristics of the storage zone such as thickness and areal extent and the temperature and pressure of the air. Minimum porosity should probably be about $10 \%$. 


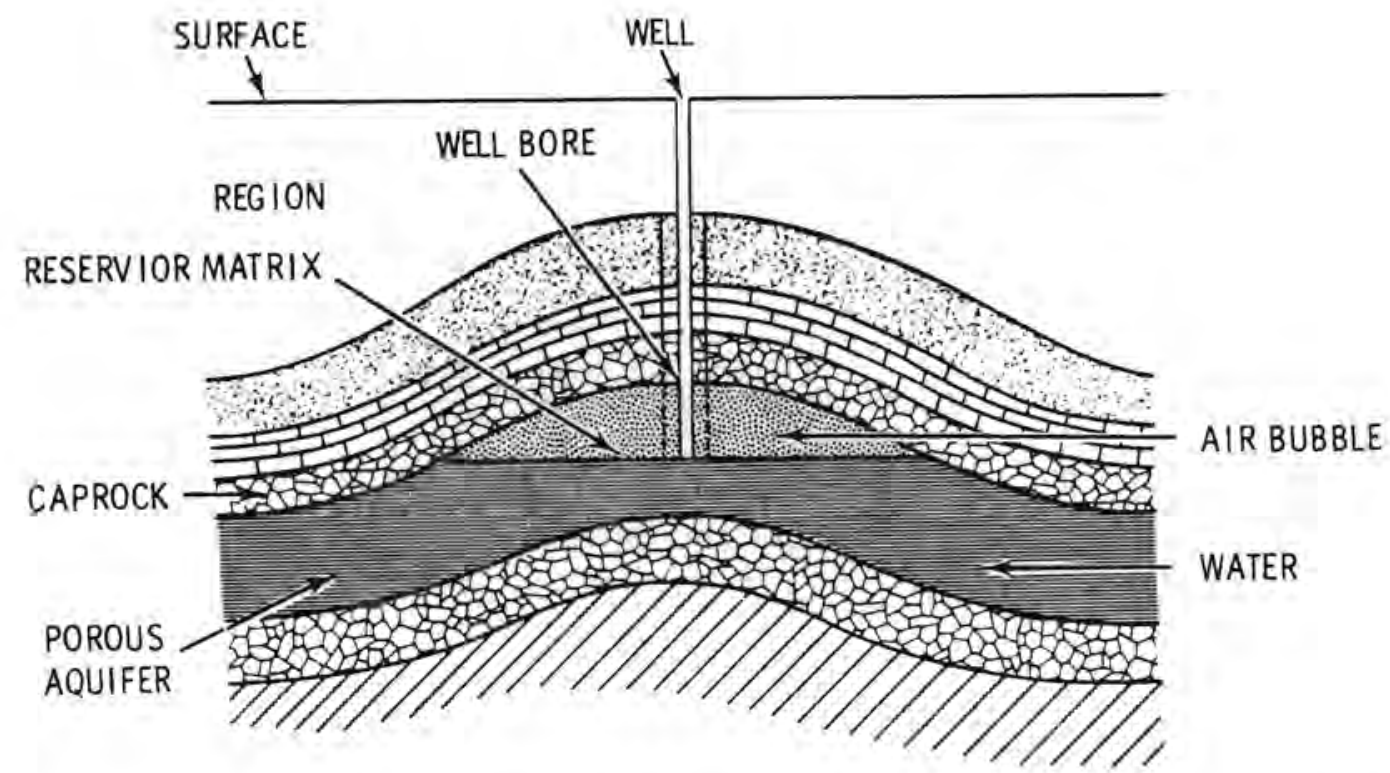

FIGURE 16. Schematic of an Aquifer System (Stottlemyre et al 1979)

- A permeability above 300 millidarcies $\left(3.0 \times 10^{-13} \mathrm{~m}^{2}\right)$ is required.

- A vertical closure in excess of $46 \mathrm{~m}(150 \mathrm{ft})$ and a centerpoint thickness in excess of $9 \mathrm{~m}(30 \mathrm{ft})$ are considered desirable for the anticlinal type of stratigraphic trap.

- The caprock should have a thickness in excess of $6 \mathrm{~m}(20 \mathrm{ft})$ to ensure volumetric integrity and adequate surface area for cement bonding of the casing within the wellbore.

- The caprock slope should be 1 ess than $15^{\circ}$ to minimize the potential for movement on possible "unrealized" glide planes.

- The caprock should have a water-displacement threshold pressure greater than twice the difference between charging pressure and reservoir discovery pressure.

- The storage zone must be deep enough to ensure that the air/water equilibrium pressure will be sufficient to deliver the required "at surface" air pressure. Hydrostatic pressure is about $9.73 \mathrm{kPa} / \mathrm{m}$ of depth $(0.43 \mathrm{psi} / \mathrm{ft})$. 
- Neither anisotropy nor heterogeneity must be dominant enough to cause sufficient wafering and channelized air spill, water entrapment, and/or gravity drainage to interfere with the efficient operation of the reservoir.

- Maximum charging pressure should not exceed $18.1 \mathrm{kPa} / \mathrm{m}(0.80 \mathrm{psi} / \mathrm{ft})$ of vertical depth. Lithostatic pressure is about $22.63 \mathrm{kPa} / \mathrm{m}(1.0$ $\mathrm{psi} / \mathrm{ft})$.

- The injection air should not subject the tubing and casing materials or completion cement to a temperature above $343^{\circ} \mathrm{C}\left(649^{\circ} \mathrm{F}\right)$.

- The injection air temperature should not be high enough to cause in situ vaporization of interstitial water.

- When developing the cushion air bubble, the first several cycles should use moderate injection air temperatures, e.g., $66^{\circ} \mathrm{C}\left(151^{\circ} \mathrm{F}\right)$, to displace water, above the residual level, within at least a $25-\mathrm{m}$ $(82 \mathrm{ft}$ ) radial zone around the wellbore.

- Radial heat transfer from the air stream to the wellbore zone of the caprock must be minimized.

- The temperature and degree of undersaturation of the injected air stream must cause net transport of water vapor out of the reservoir.

- A state of total interstitial dehydration must be rapidly attained and continualiy maintained in the near-wellbore region.

- In situ evaporation of the residual water with undersaturated air appears to be the favored mechanism for dehydration of the nearwell lbore region.

- The temperature within a vertical span of caprock should attenuate to ambient within a distance of about one meter $(3.28 \mathrm{ft})$ above the reservoir. 


\subsection{NUMERICAL MODELING}

The objective of mathematical modeling (Smith et al 1978) is to help establish preliminary stability and design criteria for CAES porous rock reservoirs based on theoretical analysis. Computer codes that incorporate both fluid flow and thermal effects were used in conjunction with data obtained from laboratory testing and from literature surveys to define expected reservoir pressure, temperature, and humidity profiles, and to examine the effects of parameter variation on reservoir performance.

Preliminary investigations of flow and thermal effects employed a dry, one-dimensional (radial) aquifer reservoir as shown in Figures 17 and 18. The model simulated cycling of heated air to and from a radial
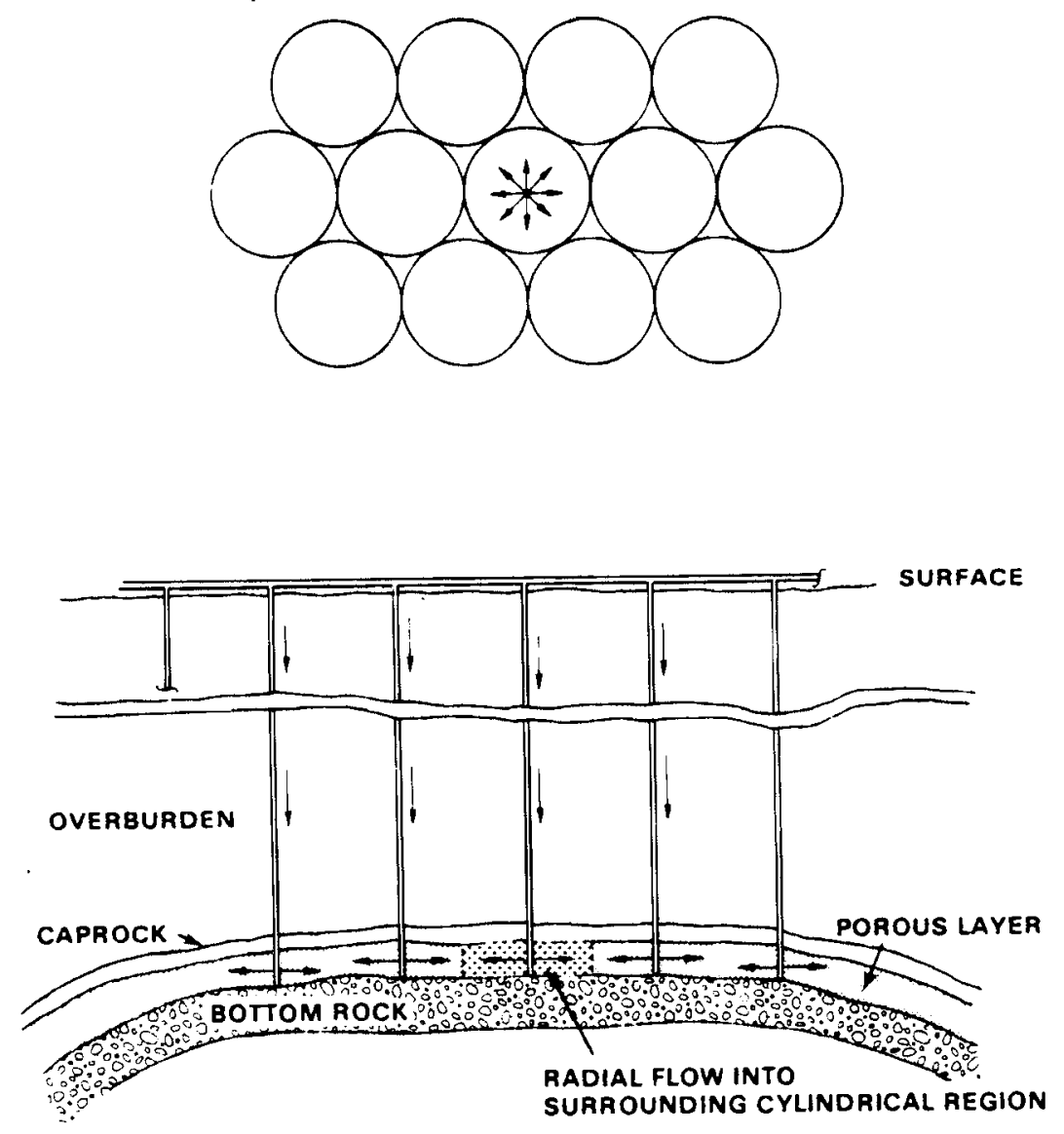

FIGURE 17. Single Well Reservoir Within CAES Reservoir (Smith and Wiles 1979) 


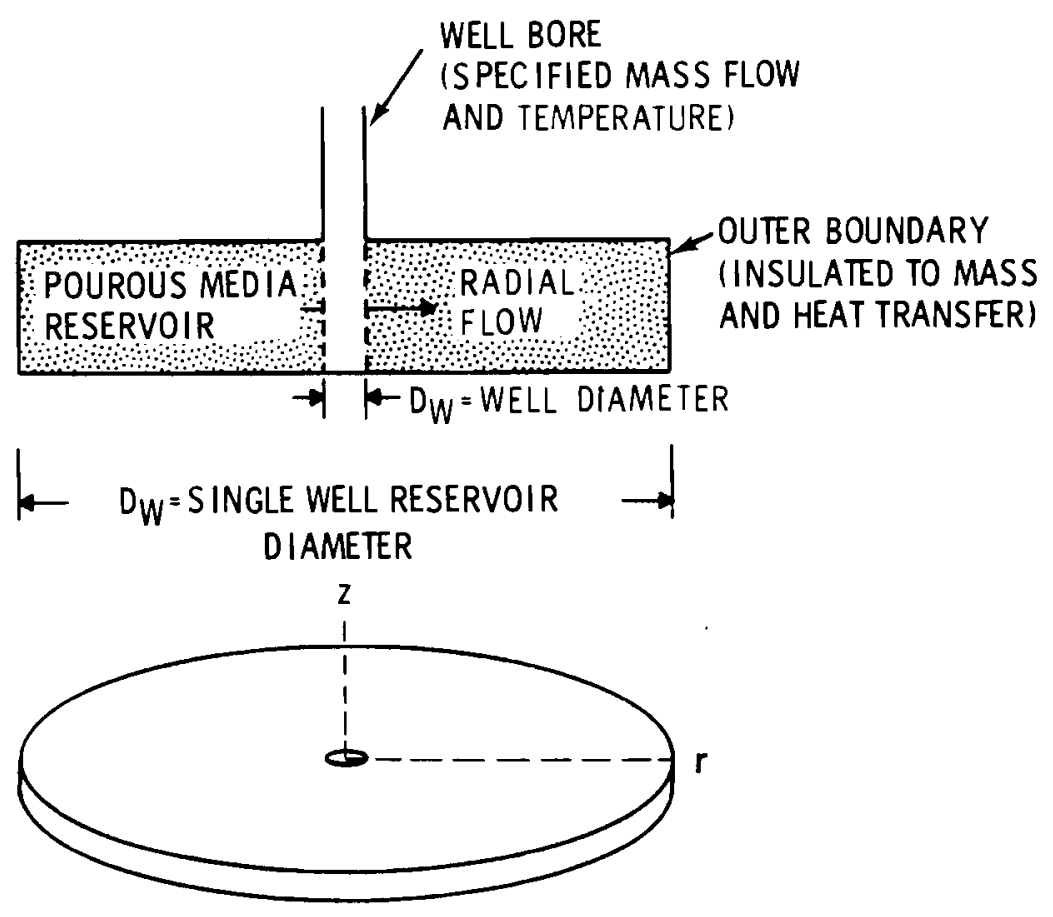

FIGURE 18. One-Dimensional Radial Reservoir (Smith and Wiles 1979)

flow field surrounding a single well in porous rock. Significant results obtained from the analysis include the following (Smith and Wiles 1979):

- The parameters having the most significant impact on the hydrodynamic behavior were the mass flow rate per unit thickness of the reservoir and the permeability of the porous material.

- The injection of hot air was shown to reduce the deliverability of compressed air from the well as the reservoir temperature increases.

- The hydrodynamic response becomes less sensitive to permeability as permeability increases.

- For a fixed number of wells and a given permeability, the hydrodynamic response is nearly independent of the void structure of the storage zone, i.e., whether the volume of the storage zone is composed of a large region of low porosity or a small region of high porosity. 
- The influence of well diameter upon the difference between well and reservoir pressures is most important at high flow rates.

- Due to the relatively large volumetric thermal capacity of the rock, most of the thermal energy injected into the reservoir is deposited within a region very near the well.

- After one year of cycling, the temperature wave did not extend beyond about $30 \mathrm{~m}(98.4 \mathrm{ft})$, with high temperatures remaining fairly localized around wells. The growth of the "thermal pillar" is slow so that even after 5 years the region more than $45 \mathrm{~m}(147.6 \mathrm{ft})$ from the wellbore is relatively unaffected.

- Assuming no wellbore heat loss, the average thermal energy recovery in the first year of simulated reservoir operation is about $73 \%$. During the tenth year of operation, approximately $88 \%$ of the injected thermal energy is recovered.

- Because of the deposition of injected thermal energy near the well during the reservoir charging cycle and the extraction of the energy during reservoir discharge, significant thermal cycling occurs in this region. For most conditions, however, the phenomenon of thermal cycling is only observable to a radius of about $3 \mathrm{~m}(9.8 \mathrm{ft})$.

- Changes in reservoir properties have little effect on thermal development with the minor exception of the thermal conductivity of the reservoir rock.

Development of a water-bearing one-dimensional radial reservoir model resulted in the following conclusions (Wiles and Oster 1978):

- A dehydrated region surrounding the well grows during mass injection of heated dry air. The progress of dehydration over five years is shown in Figure 19.

- A sharp interface, known as the "dry front", separates the dehydrated zone from the region still containing liquid water. 


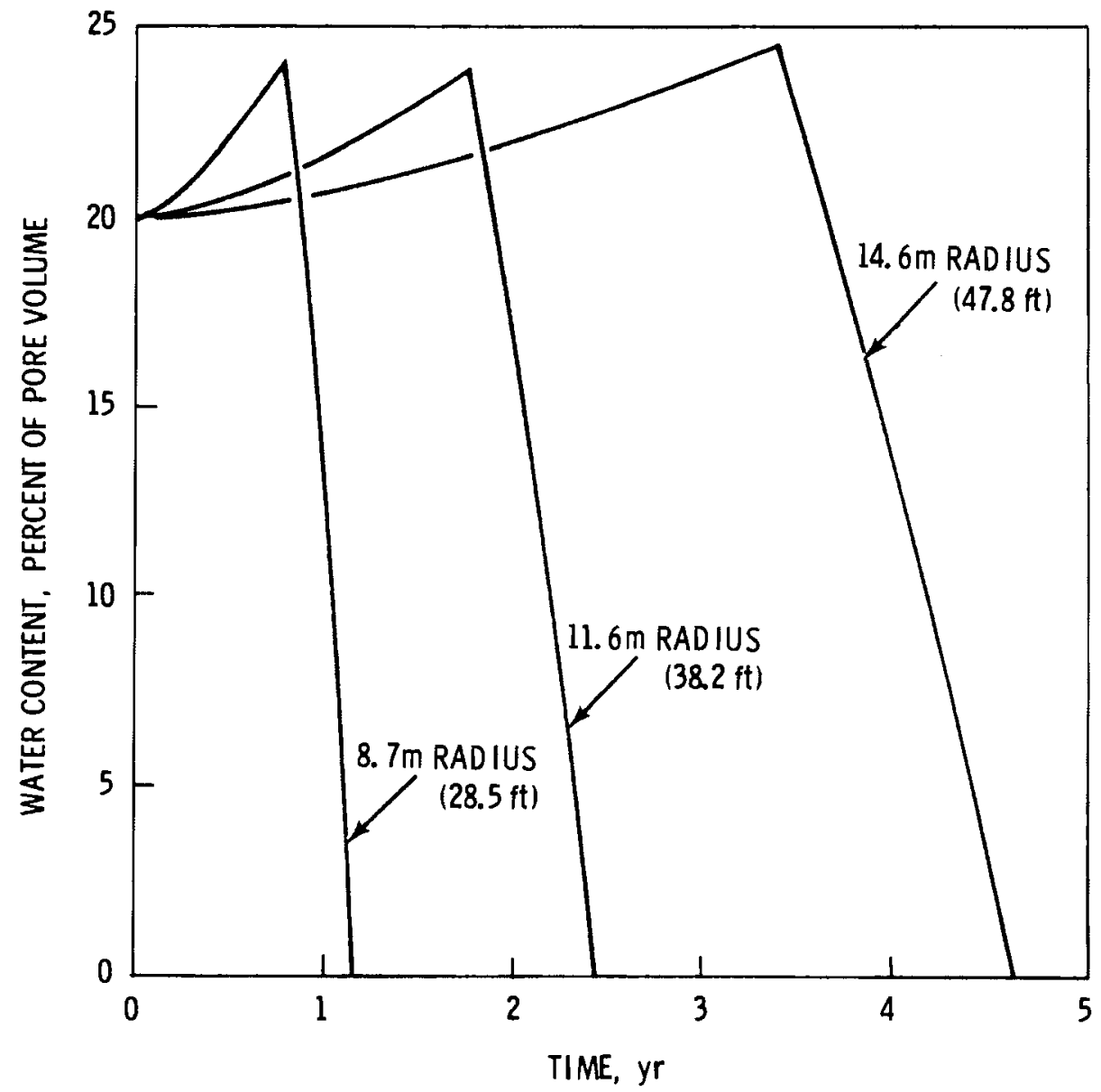

FIGURE 19. Dehydration for Three Locations (5-Year History) (Wiles and Oster 1978)

- After 5 years of continuous reservoir operation on $7 y$ 5. $5 \%$ of the original water mass has been removed and the net increase in reservoir storage volume is only $1.1 \%$.

- Although large temperature swings occur at the well boundary, thermal cycling is almost non-existent $4.27 \mathrm{~m}(14.0 \mathrm{ft})$ from the well center. Heating beyond this radius occurs mainly by conduction.

- Assuming no wel1bore heat loss, the average therma 1 energy recovery over the first 5 years of operation is about $81 \%$. The average recovery for a dry reservoir is about $82 \%$. This comparison suggests that residual water will have little effect on temperature cycling and thermal growth. 
- Outward migration velocity of the dry front varies directly with injection temperature.

- Net reservoir dehydration rates increase with injection temperature but decrease with time.

- Dehydration is significantly slowed by injection of humid air.

- Conservative reservoir design dictates that relatively dry air be injected to decrease the potential for pore plugging due to near wellbore condensation.

- The thermal capacity of the residual liquid water in an aquifer CAES reservoir will generally be small relative to the thermal capacity of the rock. Therefore, residual water content will not have a large effect upon thermal development provided the water remains a liquid.

A dry two-dimensional model (Wiles and Oster 1978) assumed dry air injection with mass energy transport in both radial and vertical directions. The following conclusions were reached:

- Very little thermal energy is conducted to the caprock and basement rock.

- Thermal energy transport within the caprock and basement rock is entirely by conduction and is extremely slow.

- Buoyancy effects are not significant in the homogeneous reservoir because no significant vertical temperature differentials exist.

- Heat transfer within the reservoir rock is mainly by forced convection in a radial direction.

- The thermal development and pressure cycling in the bulk of the reservoir agrees with that predicted by the one-dimensional model. Therefore, the less costly one-dimensional model is a reasonable tool for describing the performance of the bulk of a homogeneous reservoir. 
- Thermal development of the reservoir, caprock and basement rock are not noticeably affected by the presence of a low permeability layer centered within the storage zone.

Continued analysis of the dry two-dimensional model (Wiles 1979) produced the following additional conclusions regarding the effects of vertical parameters.

- Recovery of thermal energy can be significantly reduced by heat losses in the wellbore.

- Wellbore thermal insulation has significant potential to improve thermal energy recovery.

- Heat losses in an uninsulated wellbore result in reduced thermal cycling and lower temperatures in the porous zone.

- Although wellbore insulation improves thermal energy recovery, the porous zone is exposed to greater extremes of thermal cycling and higher temperatures. Further, insulation may increase thermal cycling of air in the wellbore for certain conditions.

- Preheating the reservoir by injecting heated air during bubble development may result in significantly improved thermal energy recovery and reduced thermal cycling during the initial weeks of reservoir operation.

- The effects of preheating dissipate rapidly. After about 20 weeks of reservoir operation, the thermal conditions of a preheated reservoir is essentially indistinguishable from a reservoir that was not preheated.

- Thermal energy recovery is strongly dependent on the residence time of the air in the wellbore.

- The most important factor in determining the thermal distribution in the porous zone is the forced-convection flow field. Producing lengths that are less than the porous zone thickness result in concentrations of thermal energy that intensify vertical temperature gradients. 
- When forced convection flow is terminated, the remaining heat transfer mechanisms are conduction in the air and porous rock, conduction to the vertical boundaries, and natural circulation. The contribution of the conductivity of the reservoir rock was shown to be the most important of these parameters.

- Natural convection flow contributes relatively little to the distribution of thermal energy.

- Heat losses to vertical boundaries can be neglected.

- The producing length of the wellbore is extremely important to the total pressure loss of the porous zone. For a given wellbore diameter, the producing length fixes the minimum flow area through which the air entering or leaving the porous zone must pass. This establishes the maximum air velocity in the porous zone and, thereby, strongly influences the total pressure drop in the reservoir.

- Air flow in the vicinity of the wellbore is predominantly radial. Therefore, reduced vertical permeability does not significantly affect the overall pressure loss in the porous zone.

- Stratification of permeability has a greater effect on pressure loss in the reservoir when the producing section extends through the layer. That is, for a given producing length, if a low-permeability layer exists below the well bottom, the effect on pressure loss will be less than if the layer is above the well bottom. This results from the dependence of the pressure drop on the permeability in the vicinity of the wellbore.

The development of a numerical computer model was initiated in FY-1980 to analyze two-phase flow in a porous medium reservoir including the effects of capillary pressure and relative permeability. Due to the difficulties of extending the computational capability to include twophase, two-dimensional flow, the thermal solution was avoided. The need for such a model has at least two origins. First, the results 
obtained previously indicated that reservoir pressure losses and temperature distributions were highly sensitive to producing length. Because of this sensitivity the producing length should be maximized. However, for reservoirs characterized by a water saturated zone below the air storage zone, the producing length will also have to be established because of the potential for water coning. During a withdrawal cycle depressurization around the wellbore will provide a potential for a cone of water to rise towards the wellbore. The intrusion of water into the near-wellbore region could dramatically affect the reservoir performance, particularly if the reservoir is being used for thermal energy storage. The conditions for which coning may occur need to be evaluated.

Secondly, the time required for bubble development may be on the order of years. The two-phase, two-dimensional model is a necessary tool to enable prediction of bubble development times for various reservoir conditions. The model could be used to optimize the time required for bubble growth.

Friley (1980) assessed the structural behavior of porous rock CAES reservoirs subjected to loading conditions of temperature and pressure typical of such an operation. Analyses addressed both mean reservoir response and cyclic response due to charge/discharge operation. The analyses assumed various geometrical and material related parameters of a generic site.

The objective was to determine the gross response of a generic porous reservoir. Site specific details such as well casing placement techniques, bore hole size, and placement depth within the porous stratum were not explicitly addressed.

The site geometry assumed a cylindrical model $122 \mathrm{~m}(400 \mathrm{ft})$ in diameter and $61 \mathrm{~m}(200 \mathrm{ft})$ high including thicknesses of the cap, porous, and base rock formations. The central portion of the porous zone was assumed to be at a depth of $518 \mathrm{~m}(1700 \mathrm{ft})$ and at an initial temperature of $20^{\circ} \mathrm{C}\left(68^{\circ} \mathrm{F}\right)$. Cyclic loading conditions of compressed air 
consisted of pressure values in the range of 4.5 to $5.2 \mathrm{MPa}$ (650 to 750 psi), and temperature values between 143 and $204^{\circ} \mathrm{C}\left(289.4\right.$ and $\left.399.2^{\circ} \mathrm{F}\right)$. Air pressures in the porous zone showed little spatial variation, whereas substantial thermal gradients existed in the central portion of the model. At the central portion of the model thermally induced stresses could be approximately twenty times larger than pore pressures. Thus, thermal structural effects are believed to exceed those due to pressure in causing rock stress levels.

Various modes of structural behavior were studied. These response modes were analyzed using loading conditions of temperature and pressure (in the porous zone) corresponding to various operational states during the first year of simulated site operation.

The response characteristics included:

- Tensile stress level in the caprock mass since this could contribute to leakage.

- Fatigue stress magnitude in the caprock and porous zone since cyclic loading will exist and is a potential reservoir damage mode.

- Porous rock stress level in relation to a Mohr Coulomb failure envelope for a Galesville sandstone.

Tensile stress levels in the caprock were observed near the end of a one year simulation. The top portion of the caprock near the wellbore was stressed by two influences. The first was radial expansion of the hot central caprock mass, which induced circumferential tensile stresses in the cooler surrounding rock. The other cause of caprock tensile stress was due to vertical thermal growth of the central porous zone. This growth caused flexure of the caprock resulting in tensile stresses on the top and compressive stresses on the bottom of the caprock layer. The magnitude of flexure strain was highly dependent on the degree of stiffness of the site overburden above the top surface of the caprock. 
Fatigue stress analysis was deemed important due to the large cyclic thermal component to which the porous zone would be subjected. Fatigue stresses in both the porous and caprock regions were concentrated in the vicinity of the wellbore. Fatigue stresses in the porous zone were greater than in the caprock zone. In both regions fatigue stresses tended to diminish during initial hot air injection and approach a steady state during the one year simulation.

Nominal (noncyclic) stress levels in the porous zone were studied with reference to a Mohr Coulomb failure envelope developed from tests on Galesville sandstone. Assumed confinement stress and pore pressure values were germain to CAES operation. The noncyclic stress levels in the porous zone were not sufficient to cause appreciable damage.

The structural analyses indicate that the most severely stressed region will likely be in the wellbore vicinity and hence highly dependent on the length of and placement technique utilized in the well production length. Analyses to address this specific area are currently being pursued.

\subsection{LABORATORY EXPERIMENTS}

Sandstone aquifers (Stottlemyre et al 1979) are potentially suitable reservoir media for the storage of compressed air at elevated temperatures. However, insufficient data currently exist to predict the physicochemical stability of reservoir rock exposed to elevated and cyclical effective stresses and temperatures. Of specific interest is reservoir stability when the interstitial fluid is dry or humidified air. Reservoir permeability, compressibility, and thermal diffusivity capacities may be affected by anticipated elevated temperature CAES conditions. Therefore, a laboratoryscale experimental program has been initiated at Pacific Northwest Laboratory. The program basically includes the following: 1) air/water/ rock interaction studies in autoclaves; 2) thermomechanical property testing in triaxial load cells; 3 ) thermal conductivity, specific heat, 
and linear thermal expansion coefficient measurements; and 4) simultaneous fluid flow, desaturation, and stress-strain testing in a prototype multiphase fluid flow facility. Only the results of the autoclave tests are available at this time.

Specimens of Galesville sandstone are subjected to heated dry air, heated humidified air, or heated aerated ground water in autoclave test chambers. Independent variables include temperature $\left(50\right.$ to $\left.300^{\circ} \mathrm{C}\right)$, hydrostatic pressure (20 to $120 \mathrm{bar}$ ), and test duration (14 to 56 days). Limitations of autoclave tests include: 1) the rock sample cannot be subjected to an effective load simulating the difference between the overburden or lithostatic pressure and the interstitial fluid pressure, 2) the fluid to rock volume ratio is unrealistically high, and 3) the advective transport of fluids through the sample cannot be controlled. The aforementioned "flow facility" will eliminate these restrictions; however, in the interim the autoclave results provide some preliminary insight concerning sandstone stability.

Galesville sandstone cores were obtained from a depth of $685 \mathrm{~m}$ $(2447 \mathrm{ft}$ ) at the Media natural gas storage facility in Illinois. Galesville is an exceedingly clean quartzose sandstone composed predominantly of silica cemented quartz sand grains. Room temperature permeability, porosity, and strength measurements were conducted before and after exposure to the autoclave conditions. The preliminary observations are:

- Exposed to dry air, the Galesville sandstone demonstrates good stability at all temperature and pressure conditions tested including the maximums of $300^{\circ} \mathrm{C}$ and 120 bars. However, if the sandstone is exposed to liquid water at temperatures above $150^{\circ} \mathrm{C}\left(302^{\circ} \mathrm{F}\right)$, changes in porosity, permeability, and friability (shear rupture strength) are observed. Results for humidified air environments were mixed and therefore additional testing is required. 
- The property changes observed in a heated aerated ground water environment are apparently due to dissolution of the cement that bonds the individual grains. Similar dissolution in an aerated steam or humidified air environment appear to be insignificant. However, the nature of autoclave experiments and the length of the tests are such that the possibility of hydrolytic weakening and time delayed grain dislocations cannot be presently dismissed for humidified air.

- Galesville sandstone is apparently insensitive to the fluid pressure and the presence of oxygen or carbon dioxide.

- Observations should not be extrapolated to actual CAES field conditions until additional data have been generated from future experiments. Statistically meaningful conclusions are not possible based on existing autoclave data.

- Further investigation is required to establish the relative importance of disaggregation caused by thermal fatigue and hydrolytic weakening. The potential consequences of pore plugging by disaggregated grains also need examination (Stottlemyre et al 1979).

To simulate the effects of pressure-temperature cycling with dry compressed air on reservoir rock and caprock, a low pressure-low temperature cycling system was developed at the University of Wisconsin-Milwaukee ${ }^{(a)}$. The system allows cyclic reversible flow tests at elevated temperature on confined samples using dry, compressed air. Typical experimental conditions were: pressure- $550 \mathrm{kPa}(80 \mathrm{psig})$ and temperature- $120^{\circ} \mathrm{C}\left(248^{\circ} \mathrm{F}\right)$. Several tests were conducted to determine the effects of this pressuretemperature cycling on reservoir rock and caprock properties. There was no indication of significant deterioration of the rocks after cyclicventilation or heating. The most important conclusions are:

(a) Cutler, Robert M., Laboratory Studies of the Effects of Compressed Air Energy Storage on Selected Reservoir Rock and Caprock, Thesis, Master of Science, Geology, The University of Wisconsin-Milwaukee, January 1979. 
- The two most important rock properties for CAES, porosity and permeability, appear to be unaffected by ventilation for a candidate reservoir rock, such as the St. Peter Sandstone.

- Although the mechanical properties of the rocks seemed to be most affected by cyclic-ventilation, no systematic changes in their values were recognizable.

- The heat capacities of rock specimens appear to be unaffected by cyclic-ventilation.

- After heating the rocks at a temperature of $260^{\circ} \mathrm{C}\left(500^{\circ} \mathrm{F}\right)$, the most noticeable changes were decreases in Young's moduli for the Bedford Limestone and the Berea Sandstone. This suggests that the thermal effects associated with compressed air may be as important as the mechanical effects. The heat capacities and porosities of the rocks were relatively unaffected by heating.

- Moderately well cemented St. Peter Sandstone, though less porous and permeable than poorly cemented St. Peter sandstone, may be better suited for use as a CAES storage medium because of superior strength and lower potential for particulate plugging.

- Although the results obtained should be useful in determining some of the possible effects of CAES on rock, confining pressure used during testing was much less than the lithostatic pressure expected in a CAES reservoir.

- To characterize the structure and lithology of the potential reservoir rock and associated caprock, subsurface drilling and core recovery are needed. Most specimens used in the cyclic ventilation study were from surface exposures.

The results of later ventilation experiments performed by $T$. B. Marsha $17^{(a)}$ on specimens taken from St. Peter, Franconia and Mt. Simon

\footnotetext{
(a) T. B. Marshall, Compressed Air Storage In Paleozoic Sandstones of Southeastern Minnesota: Thesis, Master of Science, Geology, The University of Wisconsin-MiTwaukee, September 1979.
} 
sandstones in southeastern Minnesota showed a slight apparent permeability increase with ventilation, but other rock properties showed no systematic changes. (In contrast, Cutler(a) found no change in permeability.)

Pincus $^{(b)}$ summarized other analytical results at the University of Wisconsin-Milwaukee for $\mathrm{FY}-1979$ as follows:

- Rock type is the most important independent variable affecting Young's modulus and compressive strength. Possibly the least influential independent variable is mean flow-through air pressure.

- Among the sandstones least affected were two specimens of St. Peter which were also the purest quartz sandstones studied.

- Where Young's modulus and compressive strength changed significantly, the mean values increased and the variances decreased with ventilation.

- Permeability is changed significantly by ventilation. The net change is an increase, the rocks with smaller original permeability showing larger increases.

- No significant changes in microstructure (by optical diffraction analysis) and in porosity were associated with ventilation.

Work is continuing in numerical modeling and in laboratory analysis at PNL as well as at the University of Wisconsin-Milwaukee and the Los Alamos Scientific Laboratory. A field study in the Midwest is also being planned.

(a) Cutler, Robert M., Laboratory Studies of the Effects of Compressed Air Energy Storage on Selected Reservoir Rock and Caprock, Thesis, Master of Science, Geology, The University of Wisconsin-Milwaukee, January 1979.

(b) H. J. Pincus, Underground Compressed Air Energy Storage Rock Mechanics and Geology Components - Sept III, Annua 7 Report 10/1/78 to $9 / 30 / 79$ University of Wisconsin-Milwaukee for Pacific Northwest Laboratory. 


\section{REFERENCES}

R. D. Allen, Thermal Energy Storage in Aquifers - Preliminary Information. PNL-3062, Pacific Northwest Laboratory, Richland, WA, December 1979.

J. K. Applegate and P. R. Donaldson, "Seismic Reflection for Geotherma 1: Techniques and Case History," Expanding the Geothermal Frontier. Vol. 3, Transactions Geothermal Resources Counci T Annual Meeting, Reno, NV 1979.

ATES Newsletter, C. F. Tsang, Editor, "A Quarterly Review of Aquifer Thermal Energy Storage," Earth Sciences Division, Lawrence Berkeley Laboratory, University of California, Vol. 1, No. 3, May 1979.

D. R. Bervig and R. W. Pinker, "An Assessment of Compressed Air Energy Storage (CAES) for the Kansas Utility System," 1978 Compressed Air Energy Storage Symposium Proceedings. CONF-780599, VoT. T, Pacific Grove, CA, January 7979.

Committee on Underground Gas Storage, The Underground Storage of GaS in the United States and Canada. XU0276, Twenty-Fifth AnnuaT Report on Statistics, American Gas Association, Ariington, VA 22209, 1975.

N. B. Crow and P. W. Kasameyer, "Monitoring Natural Subsidence and Seismicity in the Imperial Valiey as a Basis for Evaluating Potential Impacts of Geothermal Production," Geothermal Energy: A Novelty Becomes Resource. Vol. 2, Transactions Geothermal Resources Council Annual Meeting, Hilo, HI, 1978.

R. P. Denlinger, W. F. Isherwood, and R. L. Kovach, "The Analys is of Gravity and Geodetic Changes Due to Reservoir Depletion at The Geysers, Northern California," Expanding the Geothermal Frontier. Vol. 3, Transactions Geothermal Resources Council Annual Meeting, Reno, NV, 1979.

B. R. Dennis and H. D. Murphy, "Borehole Temperature Survey Analysis Hot Dry Rock Geothermal Reservoir," Geothermal Energy: A Novelty Becomes Resource. Vol. 2, Transactions Geothermal Resources Council Annua T Meeting, Hi To, HI, 1978.

L. H. Eilers, L. K. Moran, E. B. Nelson, L. B. Spangle, B. E. Simpson, and J. F. Williams, "Development of Geothermal Well Completion Systems I," Geothermal Energy: A Novelty Becomes Resource. Vo1. 2, Transactions Geothermal Resources CounciT Annual Meeting, HiTo, HI, 1978.

J. R. Friley, Structural Analysis of Porous Rock Reservoirs Subjected to Conditions of Compressed Air Energy Storage. PNL-3231, Pacific Northwest Laboratory, Richland, WA, January 1980. 
B. Godare, "Geothermal Wellheads - The Heat of Geothermal Production Systems," Geothermal Energy: A Novelty Becomes Resource. Vol. 2, Transactions Geothermal Resources Council Annual Meeting, Hilo, HI, 1978.

C. B. Goranson and R. C. Schroeder, "Site Specific Geothermal Reservoir Engineering Activities at Lawrence Berkeley Laboratory," Expanding the Geothermal Frontier. Vol. 3, Transactions Geothermal Resources Council Annual Meeting, Reno, NV, 1979.

J. Haney, C. Goranson, R. Solbau, and R. Schroeder, "A Review of LBL Geothermal We11 Testing Equipment," Expanding the Geothermal Frontier. Vol. 3, Transactions Geothermal Resources Council Annual Meeting, Reno, NV, 1979.

M. J. Hobson, E. G. Heath, A. J. Giramonti and W. A. Adent, "Feasibility of CAES in California," 1978 Compressed Air Energy Storage Symposium Proceedings. CONF-780599, Vo 1. 1, Pacific Grove, CA, January 1979.

M. J. Hobson et a1, Feasibility of Compressed Air Energy Storage as a Peak Shaving Technique in California. Report to California Energy Commission by Acres American, Inc., Buffa10, NY, 1978.

G. R. Jiracek and M. T. Gerety, "Comparison of Surface and Downhole Resistivity Mapping of Geothermal Reservoirs in New Mexico," Geothermal Energy: A Novelty Becomes Resource. Vo1. 2, Transactions Geothermal Resources Council Annual Meeting, Hilo, HI, 1978.

T. Karisson, "Casing Design for High Temperature Geothermal Wells," Geotherma 1 Energy: A Novelty Becomes Resource. Vol. 2, Transactions Geotherma 1 Resources Council Annual Meeting, Hi1o, HI, 1978.

D. L. Katz and K. H. Coats, Underground Storage of Fluids. UTrich's Books, Inc., Ann Arbor, MI, 1968.

D. L. Katz and E. R. Lady, Compressed Air Storage. UTrich's Books, Inc., Ann Arbor, MI, 1976.

D. L. Katz and P. A. Witherspoon, "Storage of Gas and $0 i 1$ to Meet Seasonal Demands," Proceedings of the Eighth World Petroleum Congress.

H. R. Kratz, E. A. Day and W. G. Ginn, "Temperature and Pressure Logging Tool Using No Down-Hole Electronics," Expanding the Geothermal Frontier. Vol. 3, Transactions Geothermal Resources Counci Annual Meeting, Reno, NV, 1979.

W. J. Lang, "Compressed Air Storage Considerations for Reef-Type Aquifer Structures in Indiana," Proceedings of the Workshop on Compressed Air Energy Storage Systems. ERDA-76-124, Airlie House, VA, 1975. 
F. J. Molz and A. D. Paar, "Experimental Study of the Storage of Thermal Energy in Confined Aquifers," presented at the 3rd Annual Thermal Energy Storage Contractors' Information Exchange Meeting, Springfield, VA, 1978.

F. J. Molz and J. C. Warman, "Confined Aquifer Experiment Heat Storage," Proceedings Thermal Energy Storage in Aquifers Workshop. Berkeley, CA, 1978.

F. J. Molz, J. C. Warman and T. E. Jones, "Aquifer Storage of Heated Water: Part I -- A Field Experiment," Ground Water. Vo1. 16, 1978.

E. B. Nelson, L. H. Eilers, L. K. Moran, L. B. Spangle, and B. E. Simpson, "Development of Geothermal Well Completion Systems, II," Expanding the Geothermal Frontier. Vol. 3, Transactions Geothermal Resources Council Annual Meeting, Reno, NV, 1979.

R. W. Nicholson, "Drilling Fluid Formation Damage in Geothermal Wells," Geothermal Energy: A Novelty Becomes Resource. Vol. 2, Transactions Geotherma Tesources Council Annual Meeting, Hilo, HI, 1978.

S. S. Papadopulos and S. P. Larson, "Aquifer Storage of Heated Water: Part - II Numerical Simulation of Field Results," Ground Water. Vol. 16, 1978.

R. A. Pettitt, Testing, Drilling, and Logging of Geothermal Test Hole GT-2, Phase II. LA-5897-PR, Los ATamos Scientific Laboratory, Los ATamos, NM, March 1975 .

P. B. Rand, "Aqueous Foams for Geothermal Drilling Fluids I. Surfactant Screening," Expanding the Geothermal Frontier. Vol. 3, Transactions Geothermal Resources Council Annual Meeting, Reno, NV, 1979.

P. L. Randolph, S. E. Foh, and J. Sinaott, "Underground Storage of Hydrogen," Proceedings of the DOE Chemical/Hydrogen Energy Systems Contractor Review. Washington, D.C., 1978.

D. L. Reddell and R. R. Davison, "Storage of Cold Water in Groundwater Aquifers for Cooling Purposes - Phase II," presented at 3rd Annual Thermal Energy Storage Contractors' Information Exchange Meeting, Springfield, VA, 1978.

D. L. Reddell, R. R. Davison and W. B. Harris, "Thermal Storage of Cold Water in Ground Water Aquifers for Cooling Purposes, "Proceedings Thermal Energy Storage in Aquifers Workshop. Berkeley, CA, 1978.

N. Rudd, "Evaluation of Caprock for Underground Compressed Air Energy Storage," 1978 Compressed Air Energy Storage Symposium Proceedings. CONF-780599, Vo 1. 1, Pacific Grove, CA, January 1979. 
S. K. Sanyal and J. M. Jusbasche, "Calculation of Geothermal Water Salinity from We11 Logs - A Statistical Approach," Expanding the Geothermal Frontier. Vol. 3, Transactions Geothermal Resources Council Annual Meeting, Reno, NV, 1979.

G. C. Smith, J. A. Stottlemyre, L. E. Wiles, W. V. Loscutoff and H. J. Pincus, FY-1977 Progress Report Stability and Design Criteria Studies for Compressed Air Energy Storage Reservoirs. PiNL-2443, Pacific Northwest Laboratory, Richland, WA, 99352, 1978.

G. C. Smith and L. E. Wiles, "Analysis of Underground Porous Reservoirs for Compressed Air Energy Storage," 1978 Compressed Air Energy Storage Symposium Proceedings. CONF-780599, VoT. 1, Pacific Grove, CA, January 1979.

J. A. Stottlemyre, R. L. Erikson and R. P. Smith, "Permeability and Friability Alterations in Quartzose Sandstones Exposed to Elevated Temperature Humidified Air," PNL-SA-7916, presented at the 1979 Mechanical and Magnetic Energy Storage Contractors' Review, Washington, D.C. 1979.

J. A. Stottlemyre, D. L. Katz and G. C. Smith, "Stability Criteria for Compressed Air Energy Storage in a Porous Rock Reservoir," 1978 Compressed Air Energy Storage Symposium Proceedings. CONF-780599, Vol. T, Pacific Grove, CA, January 1979.

J. A. Stottlemyre and W. V. Loscutoff, "Environmental Concerns for Compressed Air Energy Storage in Porous Media Systems," 1978 Compressed Air Energy Storage Symposium Proceedings. CONF-780599, VoT. 2, Pacific Grove, CA, January 1979.

W. J. Subcasky, "Petroleum Industry Experience in Water Injection," Proceedings Thermal Energy Storage in Aquifers Workshop. Berkeley, CA, 1978.

A. F. Veneruso and H. M. Stoller, "High Temperature Instrumentation for Geothermal Applications," Geothermal Energy: A Novel ty Becomes Resource. Vol. 2, Transactions Geothermal Resources Counci T Annual Meeting, Hilo, HI, 1978.

A. F. Veneruso and H. M. Stoller, "High Temperature Instrumentation Development and Commercialization for Geothermal Applications," Expanding the Geothermal Frontier. Vol. 3, Transactions Geothermal Resources Council Meeting, Reno, NV, 1979.

F. Wallace and D. Bervig, Geologic Assessment of Compressed Air Storage Sites in Kansas. EPRI-EM-877, Report to Electric Power Research Institute by BTack and Veatch, Kansas City, MO, 64114, 1978. 
J. C. Warman and F. J. Molz, "Subsurface Waste Heat Storage Experimental Study," Proceedings 2nd Annual Thermal Energy Storage Contractors' Information Exchange Meeting. CONF-770955, Gatlinburg, TN, 1977.

K. D. Weinstein, E. G. Tarr, J. S. Mahan and W. R. Adolphson, Geologic Issues Related to Compressed Air Energy Storage. Report to U.S. Department of Energy by Booz. Allen and Hamil ton, Inc. Bethesda, MD 20014, 1978.

L .E. Wiles and C. A. Oster, "Fluid Flow and Thermal Analys is for CAES in Porous Rock Reservoirs," Proceedings of the 1978 Mechanical and Magnetic Energy Storage Contractors Review Meeting. CONF-7810 $\overline{46}$, Luray, VA, 1978 .

L. E. Wiles, Numerical Analysis of Temperature and Flow Effects in a Dry, Two-Dimensional, Porous-Media Reservoir Used for Compressed Air Energy Storage. PNL-3047, Pacific Northwest Laboratory, Richland, WA, 99352, 1979.

J. W. Wonn, "Acoustic Sensor Development for Geothermal Borehole Televiewer," Geothermal Energy: A Novel ty Becomes Resource. Vo1. 2, Transactions Geotherma1 Resources Counci1 Annua T Meeting, Hi10, HI, 1978. 

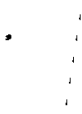

.

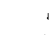


PNL -3294

UC-94b

\section{DISTRIBUTION}

No. of

Copies

OFFSITE
A. A. Churm
DOE Chicago Patent Group
Chicago Operations Office
9800 South Cass Avenue
Argonne, IL 60439

27 DOE Technical Information Center

B. J. Mueller

Department of Energy

Chicago Operations Office

9800 S. Cass Avenue

Argonne, IL 60439

Chief, APMBR

Division of Energy Storage Systems

U.S. Department of Energy

Washington, DC 20585

Dan $\mathrm{Hall}$

P.0. 635

Fairvault, MN 55021

Roya 7 B. Newman

Soyland Power Cooperative, Inc. P0 Box A1606

Decatur, IL 62525

G. D. Pezdirtz, Director

Division of Energy Storage Systems

U.S. Department of Energy

Washington, DC 20585

5 Gabor D. Karadi

Department of Energy

Division of Energy Storage

600 E Street, Room 416

Washington, DC 20585
No. of

Copies

5 Saul Strauch

DOE Division of Energy Storage Systems

Advanced Physical Methods

Branch

600 E Street, Room 416

Washington, DC 20585

J. H. Swisher

Division of Energy Storage Systems

U.S. Department of Energy

Washington, DC 20585

D. W. Boehm

Division of Environmental

Control Technology

U.S. Department of Energy

Washington, DC 20585

Assistant Director for Major

Projects

Division of Solar Energy

U.S. Department of Energy

Washington, DC 20585

Assistant Director for Thermal

Power Systems

Division of Solar Energy

U.S. Department of Energy

Washington, DC 20585

DOE Library

U.S. Department of Energy

Mail Station G-043

Washington, DC 20585

R.F. Kimberlin

DOE Library

U.S. Department of Energy

Room 1223

Washington, DC 20585 
No. of

Copies

D. Willett

Acres American, Inc.

Liberty Bank Building

Main at Court

Buffalo, NY 14202

L. A. Wilson

Middle South Services

P.0. Box 61000

New Orleans, LA 70161

Division of Advanced Energy

Research and Technology

National Science Foundation

Room 1140

1800 G Street, NW

Washington, DC 20550

C. G. Nelson

Manager, Storage Operations Northern Illinois Gas

Company

P.0. Box 190

Aurora, IL 60507

P. E. Schaub

Potomac Electric Power

Company

1900 Pennsylvania Avenue

Washington, DC 20006

T. McCafferty

Public Service Company of Indiana

1000 E. Main Street

Plainfield, IN 46168

Jim Blacic

G-6-LASL-Stop 978

PO Box 1663

Los Alamos, NM 87545

C. Cooley

Terra Tek Inc.

University Research Park

400 Wakara Way

Salt Lake City, UT 84108
No. of

Copies

2 Technical Library

Department 3141

Sandia Laboratory

Albuquerque, NM 87115

S. Serata

Serata Geomechanics, Inc.

1229 Eighth Street

Berkeley, CA 94710

Energy Research Section

Tennessee Valley Authority

1360 Commerce Union Bank Bldg.

Chattanooga, TN 37401

Gerald Phillips

Tennessee Valley Authority

1150 Chestnut, Tower 2

Chattanooga, TN 37401

E. Berman

Technical Library

TRW Energy Systems Group

7600 Colshire Drive

McLean, VA 22101

E. H. King

Underground Design Consultants

820 Cascade Bldg.

Portland, OR 97204

A. J. Giramonti

United Technologies Research Center

Silver Lane

East Hartford, CT 06108

H. J. Pincus

University of Wisconsin

Department of Geological

Sciences

Sabin Hall and Greene Museum

P.0. Box 413

Milwaukee, WI 53201 
No. of

Copies

D. Ayers

Manager, Fluid Systems Laboratory

Westinghouse Electric Corporation

1291 Cumberland Avenue

West Lafayett, IL 47906

American Public Power

Association

2600 Virginia Avenue, NW

Washington, DC 20037

2 J.M. Clinch

Argonne National Laboratory

9700 South Cass Avenue

Argonne, IL 60439

Manager, Research and

Development

Bonneville Power

Administration

P.0. Box 3621

Portland, OR 97208

Research Library, Reference Section

Information Division

Brookhaven National Laboratory

Upton, NY 11973

Stanley Stys

Vice President, American

Brown Boveri Corporation

New Brunswick, NJ 08902

Director of Research

Cincinnati Gas and and Electric Company

139 East Fourth Street

Cincinnati, OH 45202

D. E. DeViney

Commonwea 1 th Edison Company

1319 South First Avenue

Maywood, IL 60153
No. of

Copies

\author{
R. A. Bell \\ Consolidated Edison Company \\ 4 Irving Place \\ New York, NY 10003 \\ T. Schneider \\ Electric Power Research \\ Institute \\ Box 10412 \\ Palo Alto, CA 94303 \\ D. Anderson \\ Fenix and Scisson, Inc. \\ P.0. Box 15609 \\ Tulsa, OK 74115 \\ Director of Research \\ GPU Service Corporation \\ 260 Cherry Hi11 Road \\ Parsippany, NJ 07054
}

A. H. Barber

Director of Marketing

Harza Engineering Company

150 S. Wacker Drive

Chicago, IL 60606

Library

Lawrence Berkeley Laboratory

University of California

B1dg. 50, Room 134

Berkeley, CA 94720

3 Technical Information Department, L-3

Lawrence Livermore Laboratory

University of California

P.0. Box 808

Livermore, CA 94550

Director of Research

Louisiana Power and Light

142 Delaronde Street

New Orleans, LA 70174 
No. of

Copies

I. Glendenning

Head of Long-Term Studies

Marchwood Engineering Labs

Southampton, England

\section{A. Ferreira \\ Electric Power Research \\ Institute \\ NEPLAN \\ 174 Brush Hill Avenue \\ West Springfield, MA 01089}

W. Stevens $(50 / 20 / 837)$

Bechtel National Inc.

Res \& Eng.

PO Box 3965

San Francisco, CA 94119

Fred Ahrens

Argonne National Laboratory

9700 South Cass Avenue

Argonne, IL 60439

Paul Gnirk

$\mathrm{Re} / \mathrm{Spec}$ Inc.

PO Box 725

Rapid City, SD 57701

Donald L. Katz

Department of Chemical

Engineering

The University of Michigan

2042 E. Engr. Bldg.

Ann Arbor, MI 48109

R. L. Thoms

Louisiana State University

Institute for Environmental

Studies

Room 42, Atkinson Hall

Baton Rouge, LA 70803

A. F. Fossum

$\mathrm{Re} / \mathrm{Spec}$ Inc.

PO Box 725

Rapid City, SD 57701
No. of

Copies

O.C. Farquhar

$U$. of Massachusetts

Dept. of Geology \& Geography

Morrill Science Center

Amherst, MA 01003

T. L. Brekke

University of California

Department of Civil Engineering

1847 Yosemite Road

Berkeley, CA 94707

$H$. Lorenzen

PB-KBB Inc.

Subservice Systems \& Technology

800 Commerce Road West

Harahan, LA 70123

A. H. Warnke

Vice President Power Supply

Central Illinois Public Service Co.

607 East Adams Street

Springfield, IL 62701

Mr. G. E. Huck

Manager of Planning

Illinois Power Company

500 South 27 th St.

Decatur, IL 62525

Mr. W. C. Walke

Project Manager

Sargent \& Lundy Engineers

55 East Monroe Street

Chicago, IL 60603

T. J. Maiman

Sta. Mech. Engr. Dept. Manager

Commonweal th Edison Co.

36 FN West

PO Box 767

Chicago, IL 60690

E. M. Mabuce

Manager-Applied Research

Corporate Planning Dept.

Union Electric Co.

PO Box 149

St. Louis, MO 63166 
No of

Copies

W. F. Kobett

CAES Project Manager

Westinghouse Electric Corp.

Combustion Turbine Sys. Div.

Long Range Development-Lab 100

PO Box 251

Concordville, PA 19331

J. C. Smith

Division of Electrical Energy Systems

Department of Energy

12 \& Pennsylvania, Room 6144

Washington, DC 20545

J. Gahimer

Department of Energy

600 "E" Street

Washington, DC 20545

C. Holt

Battelle Columbus Laboratories

505 King Avenue

Columbus, $\mathrm{OH} 43201$

T. Barlow

Lawrence Livermore Laboratory

P0 Box 808

Livermore, CA 94550

H. M. Dodd

Organization 5743

Sandia Labs

Albuquerque, NM 87115

R. 0 . Woods

Sandia Laboratories

Org. No. 4715

Aibuquerque, NM 87115

J. L. Nash-Webber

MIT

Energy Lab

Cambridge, MA 02139
No. of

Copies

R. D. Lessard

United Technologies Research Center

Silver Lane

East Hartford, CT 06108

M. J. Hobson

Acres American, Inc.

The Clark Bldg

Suite 329

Columbia, MD 21044

ONSITE

DOE Richland Operations

Office

D. K. Jones

H. E. Ransom

Pacific Northwest Laboratory

R.D. Allen (15)

M.C.C. Bampton

S.M. Brown

T.J. Doherty

M.K. Drost

R.L. Erikson

J.A. Fort

J.R. Friley

P.J. Gutknecht (15)

A.J. Haverfield

J.J. Jacobson

L.D. Kannberg

W.S. Kelly

W.V. Loscutoff (15)

R.P. Marshall

R.A. McCann

M.A. Mckinnon

L.T. Pedersen

R.W. Reilly

R.P. Smith

J.A. Stottlemyre

A.M. Sutey

D.S. Trent

L.E. Wiles

Technical Information (5)

Publishing Coordination (2) 
